\title{
Marine fish diversity: history of knowledge and discovery (Pisces)
}

\author{
WILLIAM N. ESCHMEYER ${ }^{1,5}$, RONALD FRICKE ${ }^{2}$, JON D. FONG ${ }^{3} \&$ DENNIS A. POLACK ${ }^{4}$ \\ ${ }^{1}$ Curator emeritus, California Academy of Sciences, San Francisco, California, U.S.A. 94118 and Research Associate, Florida \\ Museum of Natural History, Gainesville, Florida, U.S.A. 32611.E-mail: weschmeyer@calacademy.org \\ ${ }^{2}$ Ichthyology, Staatliches Museum für Naturkunde, Rosenstein 1, 70191 Stuttgart, Germany. E-mail: Ronald.fricke@smns-bw.de \\ ${ }^{3}$ California Academy of Sciences, San Francisco, California, U.S.A. 94118. E-mail: jfong@ calacademy.org \\ ${ }^{4}$ P.O. Box 518, Halfway House 1685, South Africa. E-mail: dennis@fishwise.cc \\ ${ }^{5}$ Corresponding Author.E-mail: weschmeyer@calacademy.org
}

\begin{abstract}
The increase in knowledge of marine fish biodiversity over the last 250 years is assessed. The Catalog of Fishes database (http://research.calacademy.org/ichthyology/catalog) on which this study is based, has been maintained for 25 years and includes information on more than 50,000 available species names of fishes, with more than 31,000 of them currently regarded as valid species. New marine species are being described at a rate of about 100-150 per year, with freshwater numbers slightly higher. In addition, over 10,000 generic names are available ones of which 3,118 are deemed valid for marine fishes (as of Feb. 19, 2010).

This report concentrates on fishes with at least some stage of their life cycle in the sea. The number of valid marine species, about 16,764 (Feb. 19, 2010), is about equal to that of freshwater fishes $(15,170)$. Valid species of fishes apparently restricted to brackish water number only 108 . The sum $(32,042)$ is more than the current total number of 31,362 , valid species of fishes because some species occur in more than one habitat.

Presented is information on the description of species and genera over historic time, the authors describing taxa, and the deemed validity of described species and genera. We characterize families and also geographic areas where marine fishes are relatively well known and those where much discovery appears to remain. Endemism is also discussed. As examples, the marine fish faunas of the Mediterranean Sea, the Red Sea and the Mascarene Islands are shown to be well known. Little new discovery has been found recently at the family level, and new discoveries of species and genera are mostly limited to certain families and geographic areas and habitats. Specialized collecting techniques are discussed. Overall success rates for valid species discovery through time has only been about 50\%, or two species described for each valid one recognized; however this percentage has been improving over time. Because of recent improvements in technology, literature availability, quality of analysis, better communication, and other factors, the current success rate for validity of species is well over $90 \%$ (with a small lag time as status is confirmed or rejected by the ichthyological community).

Two habitats where most new marine taxa will likely be found are deep-reefs and deep-slopes, areas poorly sampled and studied. Some deep-sea areas, particularly in the Southern Hemisphere and throughout the Indian Ocean and in Indonesia, should reveal many new taxa from increased collecting efforts. Molecular genetic studies are proving valuable in phylogenetic and phylogeographic analyses as well as in species' population analyses, but these relatively new techniques are not uncovering large numbers of new or cryptic taxa.

An estimate of marine fish species yet to be sampled and described is about 5,000, or twice the number described in the last 19 years, for a projected total of approximately 21,800 valid marine species of fishes.
\end{abstract}

Key words: Marine fishes (all), history of discovery, taxonomy, valid taxa, statistics of discovery, biogeography, families, genera, species

\section{Introduction}

Taxonomy is an on-going endeavor. The basic knowledge of diversity through species discovery and description is mostly complete for some areas of the world and for many families of fishes, but important gaps remain. The present study is an analysis of the scientific discovery and description of marine fish taxa over 
time. Fishes constitute more than half of all vertebrates, with over 31,000 valid species, and of these over half are marine fishes.

The Catalog of Fishes database was begun in the 1980s at the California Academy of Sciences where it is maintained and updated continuously. Two large publications have resulted from it: the "Genera of Fishes" (Eschmeyer \& Bailey 1990) and the "Catalog of Fishes" (Eschmeyer 1998a); online versions have been updated several times each year since 1997. The database is available online at http:// research.calacademy.org/research/ichthyology/catalog/fishcatmain.asp.

The Catalog of Fishes database was designed especially for ichthyologists and other biologists, and includes a large audience seeking accurate information on fish taxonomy, including evolutionary and environmental biologists, fisheries workers and ecologists. It is an on-going summary of current knowledge of the kinds of fishes. Special efforts were made to provide accurate spellings of taxonomic names, information on the location of type specimens, and reliable information on dates of publication, correct authorship and other technical details. Nearly all original descriptions of species and genera were examined. Information in the database has been incorporated into the independent Fishbase database and several other initiatives in recent years. From the Catalog of Fishes database, we are able to analyze a number of trends, and provide a number of graphs and tables to document the history of discovery of marine fishes.

Mora et al. (2008) used records from the Ocean Biogeographical Information System (OBIS) database (http://www.obis.org) to estimate the completeness of the global fish inventory through the extrapolation of species discovery curves. They estimated that the global inventory is about $79 \%$ complete, or that $21 \%$ of marine fishes remain to be discovered, based on about 15,700 currently known. In the present study, a different approach is used, involving analysis by families of fishes and their distribution and biology, analysis of geographic areas and basins, and descriptions of new species through time, and from various habitats. Compared to Mora et al. (2008), our estimates are somewhat higher, reflecting more species from habitats under-represented in their data, different assumptions, and consideration of biological factors.

\section{Methods}

The printed version of the Catalog of Fishes (Eschmeyer 1998a) provides information on the database and its preparation and content. In this paper we include information on all taxa described by the end of 2009. Figures and tables were prepared from information taken from the online version of 19 February 2010 (for data through 2009). The database uses MS SQL Server 2005 and MS Access. The figures were prepared in MS Excel. Some graphs and tables are presented in 5- or 10-year periods, except the first time period includes the extra year 1758 making it a 6- or 11-year period.

Definitions important to this paper are: Marine fishes: Species that spend at least a part of their life cycle in the sea. This includes anadromous species, such as salmon, as well as catadromous and amphidromous species. Available name: A scientific name that meets the criteria of publication, authorship and other restrictions of the international Code of Zoological Nomenclature; it is a name that may be used in zoological nomenclature. Generally, we are concerned only with available names. Valid name: A species, subspecies or genus that is considered to be a legitimate and recognizable "good" taxon. Synonym: A taxon considered to be a junior synonym (duplicate) of a taxon describe earlier. Primary type locality: The geographic locality of the primary name-bearing type specimens (holotype, lectotype, neotype or syntypes). Species-group name: The scientific name of a species or subspecies; for this analysis, specific and subspecific names are grouped together as species-group taxa; a subspecies can be raised to a species or a species reduced to a subspecies with no change in availability, spelling or authorship. Genus-group name: The scientific name of a genus or subgenus; for this analysis, generic and subgeneric names are grouped together as generic-group taxa.

Endemism (endemic): Restricted in distribution to a specific geographic area (e.g., a species endemic to the Hawaiian Islands). Status of taxa: Three categories are used-valid, uncertain, synonym. Species habitats: Where a species lives; for this analysis a species may occur in one to three habitats—fresh, brackish or marine waters. 


\section{Results and discussion}

Species over time. Descriptions of new fish species over time varies widely (Table 1, Fig. 1) for a variety of reasons. The great exploring expeditions of the mid-1800's provided high peaks in new marine species descriptions. And, in the late 1800s and early 1900s, American marine expeditions produced another significant peak. During the 1940s, a number of new workers entered the discipline. The advent of SCUBA and use of ichthyocides (mainly rotenone) resulted in the discovery and description of many new marine species since 1950, and there were significantly more researchers in subsequent years. The total number of authors of marine fish species was about 2,300 (as of the end of 2009), and the number of authors of names for all habitats was about 4,300.

TABLE 1. Number of new marine species-level taxa (species and subspecies), number of names now considered to be valid, and the total number of authors describing those taxa, per 5-year periods.

\begin{tabular}{llllllll}
\hline Years & New Taxa & Valid & Authors & Years & New Taxa & Valid & Authors \\
\hline $1758-1763$ & 321 & 263 & 2 & $1884-1888$ & 652 & 248 & 61 \\
$1764-1768$ & 98 & 48 & 11 & $1889-1893$ & 585 & 381 & 53 \\
$1769-1773$ & 60 & 28 & 10 & $1894-1898$ & 618 & 334 & 69 \\
$1774-1778$ & 168 & 100 & 14 & $1899-1903$ & 932 & 469 & 67 \\
$1779-1783$ & 64 & 35 & 13 & $1904-1908$ & 1217 & 582 & 88 \\
$1784-1788$ & 161 & 73 & 18 & $1909-1913$ & 1008 & 530 & 89 \\
$1789-1793$ & 471 & 151 & 17 & $1914-1918$ & 619 & 292 & 64 \\
$1794-1798$ & 87 & 40 & 14 & $1919-1923$ & 466 & 223 & 64 \\
$1799-1803$ & 1009 & 267 & 17 & $1924-1928$ & 733 & 324 & 95 \\
$1804-1808$ & 96 & 20 & 12 & $1929-1933$ & 952 & 398 & 113 \\
$1809-1813$ & 367 & 93 & 15 & $1934-1938$ & 1058 & 444 & 121 \\
$1814-1818$ & 377 & 104 & 15 & $1939-1943$ & 551 & 259 & 88 \\
$1819-1823$ & 213 & 72 & 31 & $1944-1948$ & 486 & 168 & 68 \\
$1824-1828$ & 621 & 189 & 32 & $1949-1953$ & 599 & 327 & 110 \\
$1829-1833$ & 1524 & 578 & 52 & $1954-1958$ & 592 & 305 & 141 \\
$1834-1838$ & 746 & 304 & 53 & $1959-1963$ & 647 & 403 & 152 \\
$1839-1843$ & 1005 & 335 & 54 & $1964-1968$ & 512 & 350 & 185 \\
$1844-1848$ & 933 & 360 & 44 & $1969-1973$ & 495 & 401 & 225 \\
$1849-1853$ & 841 & 325 & 48 & $1974-1978$ & 663 & 574 & 273 \\
$1854-1858$ & 1232 & 397 & 43 & $1979-1983$ & 832 & 759 & 320 \\
$1859-1863$ & 1161 & 421 & 46 & $1984-1988$ & 740 & 677 & 330 \\
$1864-1868$ & 772 & 287 & 45 & $1989-1993$ & 608 & 578 & 276 \\
$1869-1873$ & 694 & 243 & 43 & $1994-1998$ & 550 & 524 & 250 \\
$1874-1878$ & 836 & 358 & 58 & $1999-2003$ & 689 & 681 & 292 \\
$1879-1883$ & 1059 & 475 & 64 & $2004-2008$ & 859 & 846 & 382 \\
\hline
\end{tabular}

Periods of high activity can be summarized as follows (numbered in Fig. 1). Stage 1, early discovery: This covers the period after Linnaeus in 1758 to about 1825. During this time, very little new material became available. Many species that had been described earlier were given new names in works authored by B. G. E. Lacepède, M. E. Bloch and J. G. Schneider, C. S. Rafinesque, W. Swainson and G. Shaw. The percentage of valid species is low and authors few. There was no "rule book" comparable to today's Code of Zoological Nomenclature (International Commission on Zoological Nomenclature, 1999). Stage 2, worldwide 
explorations: This covers the period from about 1825 to about 1895 , especially the mid-1800s. This was a time of the great marine expeditions by Europeans. There was much new material collected, including many surprising discoveries. A code of nomenclature was established in 1842 [for an interpretation and history see Eschmeyer (1998b, Appendix A)]. Stage 3, focused exploration: The period from about 1890 to 1920, saw extensive American marine expeditions (e.g., Hawaiian Islands, Alaska, Bering Sea, Galapagos), and increased deep-sea exploration by explorers from several countries. Many monographs on many groups of fishes and geographical areas were published by David Starr Jordan and his co-workers. The number of professional ichthyologists remained low, however. Stage 4, increased workers: This stage reached a peak during the 1920s-1950s. There was an increase in taxonomic workers, and in the publication of regional studies on marine fishes by such ichthyologists as H.W. Fowler, G. P. Whitley, Carl L. Hubbs and J.L.B. Smith. Stage 5, new exploration, new techniques: After 1950, there was less exploration of offshore and deep-sea areas, but much concentration in search for fishable commercial stocks. However, some significant exploration of deep-sea and mid-water depths was undertaken, especially by German and Russian scientists. Some geographic areas and many taxonomic groups (especially commercially important ones) became relatively well studied. Technological advances contributed to ease of study. SCUBA was introduced, there were many more workers, and new geographical areas were studied.

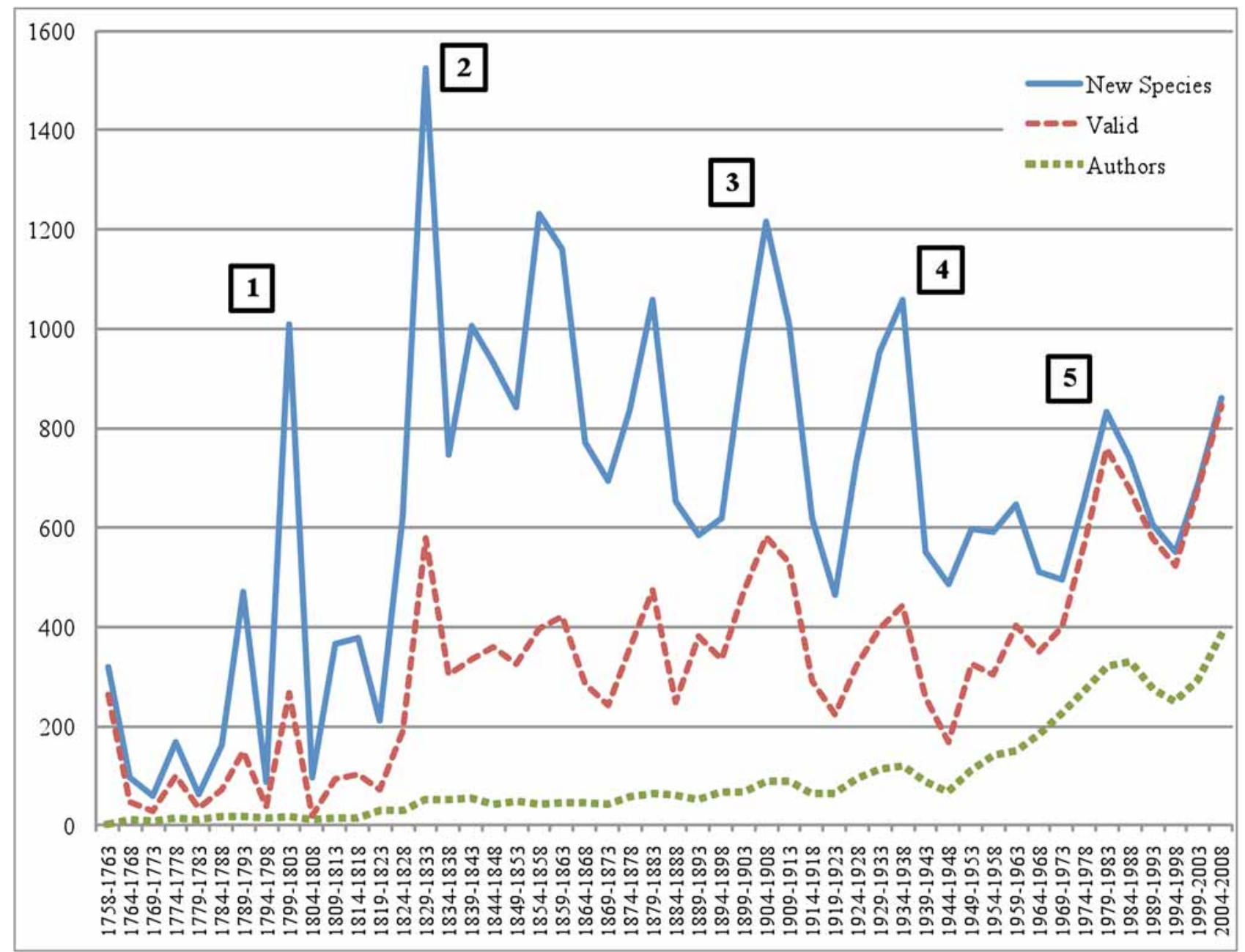

FIGURE 1. Number of new marine species-level taxa (species and subspecies), number of names considered to be valid (as species), and total number of authors, per 5-year periods.

After 1950 and increasing to the present, ichthyological studies became more efficient with better tools, such as SCUBA (and just recently re-breathers), use of rotenone and other ichthyocides, manned and robotic submersibles, molecular genetic studies, better communication, the Internet, computers, photocopiers 
followed by scanners, portable document format (PDFs), team approach, digital photography, online literature, the Catalog of Fishes and Fishbase, electronic journals, and more publication outlets. The sophistication and accuracy of description of new taxa increased substantially.

Use of subspecies rank in marine fishes. Subspecies are species-group names, and a subspecies may be elevated in rank to a full species with no change in authorship and date. On the other hand, a taxon described as a new species can be demoted later to subspecies rank. Subspecies were much more commonly used in earlier literature than now. Table 2 illustrates the increase in description of (full) species and the decline of the use of subspecies since 1940 in marine taxa.

TABLE 2. Average number of marine species and subspecies per 10-year period since 1940, and percent of total described as subspecies.

\begin{tabular}{lllll}
\hline Period & Species & Subspecies & \% Subsp. & Total \\
\hline $1940-1949$ & 85 & 9 & 11.52 & 94 \\
$1950-1959$ & 118 & 11 & 9.63 & 129 \\
$1960-1969$ & 101 & 5 & 5.59 & 106 \\
$1970-1979$ & 114 & 5 & 4.63 & 119 \\
$1980-1989$ & 153 & 3 & 2.15 & 156 \\
$1990-1999$ & 117 & 1 & 1.53 & 118 \\
$2000-2009$ & 150 & 1 & 0.67 & 151 \\
\hline
\end{tabular}

The concept of subspecies has changed through time. Some authors used subspecies to identify closely related populations that were not overlapping in distribution and usually showed differences that were considered minor. More recent studies suggest that if populations show consistent differences and lack zones of integration, they can be regarded as full species, especially with molecular confirmation. In freshwater, the use of subspecies has similarly declined-if populations are in long-separated basins, they are usually now called full species.

The proportion of subspecies described has declined in every decade since 1940 (Table 2). For the period 1940-1949, the average number of species described annually was 85, while an average of nine subspecies were described per year. In 2000-2009, an average of 150 new marine species and only one marine subspecies were described per year. Subspecies are now recognized mostly in only a few oceanic families with populations occurring in two or more ocean basins. Examples of currently recognized subspecies are found in tropical marine families such as flyingfishes (Exocoetidae), halfbeaks (Hemiramphidae), and a few others.

Authors of new species. The number of authors of names of new marine fish species also has changed substantially through time (Table 1, Fig. 1). Until about 1880, fewer than 60 authors per each 5-year period were responsible for describing all new species, and nearly all of them were men associated with major natural history museums. In general, the specimens went to the museums, having been collected by professional collectors and ichthyologists working for government agencies, universities, or museums. Since 1950, there has been an increase in number of authors, often including technicians and collectors.

A major change is that the describers of new marine species have "gone to obtain the specimens" rather than the specimens coming to them. This includes many ichthyologists employing SCUBA to observe and collect, such as John Randall, Gerald Allen, Richard Pyle and Ross Robertson among many others, and other biologists participating directly in trawling operations and in field collecting. They see the specimens in fresh condition, can use digital photography to document live colors, usually employ global positioning systems (GPS), and often use specialized techniques. This contrasts to the early years when the specimens were brought to the museum specialist, at most accompanied by a color drawing or painting. The early workers tended to publish alone or with one co-author and without peer review, whereas more recent authors often publish with one to often several co-authors and most journals require rigorous peer review of their manuscripts. 
TABLE 3. Number of described and valid marine species-level taxa (species and subspecies) described by the 50 most prolific authors, from 1758 through 2009, including their success rate (\% valid as species) and year of first publication.

\begin{tabular}{|c|c|c|c|c|c|}
\hline Rank & Author & Described & Valid & $\%$ Valid & First Publication \\
\hline 1 & Bleeker P. & 1373 & 571 & 41.59 & 1846 \\
\hline 2 & Valenciennes A. & 1247 & 459 & 36.81 & 1821 \\
\hline 3 & Jordan D. S. & 1068 & 575 & 53.84 & 1878 \\
\hline 4 & Günther A. & 988 & 551 & 55.77 & 1859 \\
\hline 5 & Cuvier G. & 950 & 383 & 40.32 & 1798 \\
\hline 6 & Fowler H. W. & 814 & 284 & 34.89 & 1900 \\
\hline 7 & Gilbert C. H. & 743 & 579 & 77.93 & 1880 \\
\hline 8 & Randall J. E. & 705 & 680 & 96.45 & 1955 \\
\hline 9 & Bloch M. E. & 577 & 223 & 38.65 & 1779 \\
\hline 10 & Regan C. T. & 518 & 281 & 54.25 & 1902 \\
\hline 11 & Lacepède B. G. E. & 490 & 113 & 23.06 & 1798 \\
\hline 12 & Whitley G. P. & 451 & 157 & 34.81 & 1926 \\
\hline 13 & Steindachner F. & 442 & 200 & 45.25 & 1860 \\
\hline 14 & Richardson J. & 431 & 182 & 42.23 & 1823 \\
\hline 15 & Poey F. & 406 & 103 & 25.37 & 1851 \\
\hline 16 & Smith J. L. B. & 386 & 189 & 48.96 & 1931 \\
\hline 17 & Linnaeus C. & 379 & 300 & 79.16 & 1758 \\
\hline 18 & Schneider J. G. & 372 & 114 & 30.65 & 1788 \\
\hline 19 & Seale A. & 315 & 86 & 27.3 & 1896 \\
\hline 20 & Castelnau F. L. & 294 & 52 & 17.69 & 1855 \\
\hline 21 & Ogilby J. D. & 272 & 118 & 43.38 & 1885 \\
\hline 22 & Allen G. R. & 271 & 256 & 94.46 & 1970 \\
\hline 23 & Garman S. & 265 & 160 & 60.38 & 1875 \\
\hline 24 & Bean T. H. & 261 & 158 & 60.54 & 1877 \\
\hline 25 & Evermann B. W. & 251 & 97 & 38.65 & 1887 \\
\hline 26 & Risso A. & 244 & 51 & 20.9 & 1810 \\
\hline 27 & Herre A. W. C. T. & 234 & 88 & 37.61 & 1903 \\
\hline 28 & Snyder J. O. & 230 & 122 & 53.04 & 1896 \\
\hline 29 & Rafinesque C. S. & 230 & 30 & 13.04 & 1810 \\
\hline 30 & Macleay W. & 227 & 44 & 19.38 & 1877 \\
\hline 31 & Gill T. N. & 223 & 104 & 46.64 & 1859 \\
\hline 32 & Walbaum J. J. & 216 & 40 & 18.52 & 1784 \\
\hline 33 & Kaup J. J. & 210 & 61 & 29.05 & 1826 \\
\hline 34 & Schultz L. P. & 196 & 107 & 54.59 & 1931 \\
\hline 35 & Schlegel H. & 195 & 142 & 72.82 & 1839 \\
\hline 36 & Goode G. B. & 192 & 129 & 67.19 & 1874 \\
\hline 37 & Rüppell W. P. E. S. & 191 & 99 & 51.83 & 1828 \\
\hline 38 & Starks E. C. & 189 & 103 & 54.5 & 1895 \\
\hline 39 & Temminck C. J. & 185 & 136 & 73.51 & 1842 \\
\hline 40 & Trewavas E. & 181 & 86 & 47.51 & 1929 \\
\hline
\end{tabular}

Continued next page 
TABLE 3. (continued)

\begin{tabular}{llllll}
\hline Rank & Author & Described & Valid & $\%$ Valid & First Publication \\
\hline 41 & Nielsen J. G. & 169 & 162 & 95.86 & 1961 \\
42 & De Vis C. W. & 167 & 17 & 10.18 & 1882 \\
43 & Hildebrand S. F. & 166 & 89 & 53.61 & 1912 \\
44 & Weber M. & 164 & 99 & 60.37 & 1905 \\
45 & Alcock A. W. & 162 & 131 & 80.86 & 1889 \\
46 & Last P. R. & 161 & 160 & 99.38 & 1978 \\
47 & Andriashev A. P. & 160 & 138 & 86.25 & 1934 \\
48 & Tanaka S. & 160 & 67 & 41.88 & 1905 \\
49 & Shaw G. & 159 & 24 & 15.09 & 1790 \\
50 & Gronow L. T. & 158 & 1 & 0.633 & 1772 \\
\hline
\end{tabular}

The authors who described the most marine species are listed in Table 3. Early workers (see date of first publication) dominated the description of new marine species. Of the top 20, all are deceased except the "living legend" John E. Randall of the Bishop Museum (Honolulu), who in 2009 ranked as number 8, and continues to publish new taxa. The top 50 includes only three other living persons (G. R. Allen at \#22, J. G. Nielsen at \#41, and P. R. Last at \#46). Randall has described the most marine species that are currently considered valid. In a tally of new species from freshwater and estuarine as well as marine habitats, the top 16 authors of described species at the end of 2009 were: Bleeker (1,926 species, $44 \%$ valid), Valenciennes $(1,843,37)$, Günther $(1,633,57)$, Fowler $(1,445,41)$, Jordan [D. S.] $(1,351,52)$, Boulenger $(1,136,69)$, Cuvier $(1,073,40)$, Steindachner $(1,032,57)$, Regan $(934,63)$, Gilbert [C. H.] (813, 76), Eigenmann [C. H.] (736, 72), Randall [J. E.] (717, 96), Bloch $(714,38)$, Lacepède $(612,23)$, Richardson $(526,40)$ and Linnaeus $(499$, 78).

The number of new species per publication (Table 4) has decreased to an average of between one and two species per publication since the period 1964-1968. This reflects new methods and fewer new marine species being found. Major revisions with several new species are usually the result of the work by one or two or three co-workers that have studied the group for many years, but these publications have become rather rare (see for example Schwarzhans et al. 2005).

Genera of marine fishes. Most new genus-level taxa in early years were described by museum-based taxonomists who had available to them the necessary comparative specimens and literature. Description of new taxa shows a decline after about 1929 until the most recent years. The numbers of new genera and subgenera of marine fishes described since 1930, in 10-year periods are shown in Figure 2. The top 25 authors of marine fish genera are listed in Table 5; all are deceased. David Starr Jordan (with his co-authors included) tops the list, followed by T. N. Gill. "Success" rates (i.e., taxa now considered valid) vary widely. For marine fishes, A. W. C. T. Herre has the worst "batting average"-only $22.6 \%$ of marine genera and subgenera he described are now considered valid, followed by Henry Fowler with $24 \%$. Peter Bleeker was a famous fieldoriented researcher, but many of his new marine genera came from southern Indonesia, which forms part of the large tropical Indo-Pacific faunal realm, thus some of them already had been described from other areas by earlier authors. Linnaeus was first to describe genera, so his success rate based on status of species at the end of 2009 is high. Other workers, such as C. T. Regan and C. H. Gilbert, had early access to major theretofore relatively unknown faunas, thus their success rates also are relatively high.

For comparison, the top 15 authors of fish genera and subgenera from all habitats through 2009 are: Jordan (604 described, 212 valid, 35\% valid), Bleeker (523, 299, 57), Fowler (479, 117, 24), Gill [T. N.] (473, 246, 52), Whitley (450, 127, 28). Günther (301, 186, 62), Eigenmann (209, 140, 67), Cuvier (206, 112, 54), Rafinesque (190, 70, 37), Evermann [C. H.] (189, 50, 26), Regan (187, 110, 59), Smith [J. L. B.] (169, 71, 42), Swainson (166, 59, 35), Hubbs [Carl L.] (140, 49, 35), Lacepède (137, 89, 65). No living fish taxonomist ranks higher than $64^{\text {th }}$ in this analysis. The top five authors of valid genera from all habitats (through 2009) are: Bleeker (299 valid), Gill [T. N.] (246), Jordan [D. S.] (212), Günther (186) and Eigenmann (140). 
TABLE 4. Yearly average number of new marine species-level taxa (species and subspecies) described per publication, per 5-year periods.

\begin{tabular}{|c|c|c|c|}
\hline Years & Avg. Taxa & Years & Avg. Taxa \\
\hline $1758-1763$ & 64.2 & $1884-1888$ & 3.9 \\
\hline $1764-1768$ & 7.0 & 1889-1893 & 4.6 \\
\hline 1769-1773 & 4.0 & 1894-1898 & 5.0 \\
\hline 1774-1778 & 12.9 & 1899-1903 & 5.4 \\
\hline 1779-1783 & 3.6 & 1904-1908 & 5.2 \\
\hline 1784-1788 & 6.0 & 1909-1913 & 5.0 \\
\hline 1789-1793 & 14.3 & 1914-1918 & 3.5 \\
\hline 1794-1798 & 4.0 & 1919-1923 & 3.6 \\
\hline 1799-1803 & 59.4 & 1924-1928 & 3.9 \\
\hline 1804-1808 & 7.4 & 1929-1933 & 3.6 \\
\hline 1809-1813 & 17.5 & 1934-1938 & 3.6 \\
\hline 1814-1818 & 10.8 & 1939-1943 & 2.9 \\
\hline 1819-1823 & 5.2 & 1944-1948 & 3.8 \\
\hline $1824-1828$ & 12.2 & 1949-1953 & 2.5 \\
\hline 1829-1833 & 17.9 & 1954-1958 & 2.1 \\
\hline 1834-1838 & 8.3 & 1959-1963 & 2.1 \\
\hline $1839-1843$ & 10.9 & 1964-1968 & 1.6 \\
\hline 1844-1848 & 10.5 & 1969-1973 & 1.6 \\
\hline 1849-1853 & 6.9 & 1974-1978 & 1.8 \\
\hline 1854-1858 & 7.8 & 1979-1983 & 1.9 \\
\hline 1859-1863 & 5.9 & 1984-1988 & 1.8 \\
\hline 1864-1868 & 4.4 & 1989-1993 & 1.6 \\
\hline 1869-1873 & 6.1 & 1994-1998 & 1.8 \\
\hline 1874-1878 & 5.1 & 1999-2003 & 1.8 \\
\hline 1879-1883 & 4.0 & 2004-2008 & 1.7 \\
\hline
\end{tabular}

Described genera of fishes, as in other taxonomic disciplines, generally experienced a break-up of the (early) Linnaeus-period inclusive genera as more species diversity was discovered. New discovery and description of marine genera now have leveled off (Fig. 3). Recently described deep-reef species are mostly relatives of species in shallow-living genera. Molecular genetic studies have resulted in some refinement of generic limits, but in many cases as new genera are named, available names rather than new names can be used. This decline in description of new genera indicates that marine fish biodiversity is becoming well known, at least at the generic level.

Different taxonomic disciplines include very different "sized" genera-with, for example, some insect and mollusk genera containing thousands of named species; concepts of generic limits also vary. More than 3,118 valid marine genera of fishes were recognized as of the end of 2009. Surprisingly, about 1,139 (about 36 $\%$ ) are monotypic (with a single valid included species) as of Feb. 2010. Marine genera with the most currently deemed valid species are Apogon (163 species), Coelorinchus (121), Gymnothorax (120), Paraliparis (118), Eustomias (117), Careproctus (116), Callionymus (109), Sebastes (109), Chromis (95) and Epinephelus (90). Nineteen species of Apogon were recently removed to Apogonichthyoides (Fraser \& Allen 2010), reducing to 144 the number of species in Apogon. 


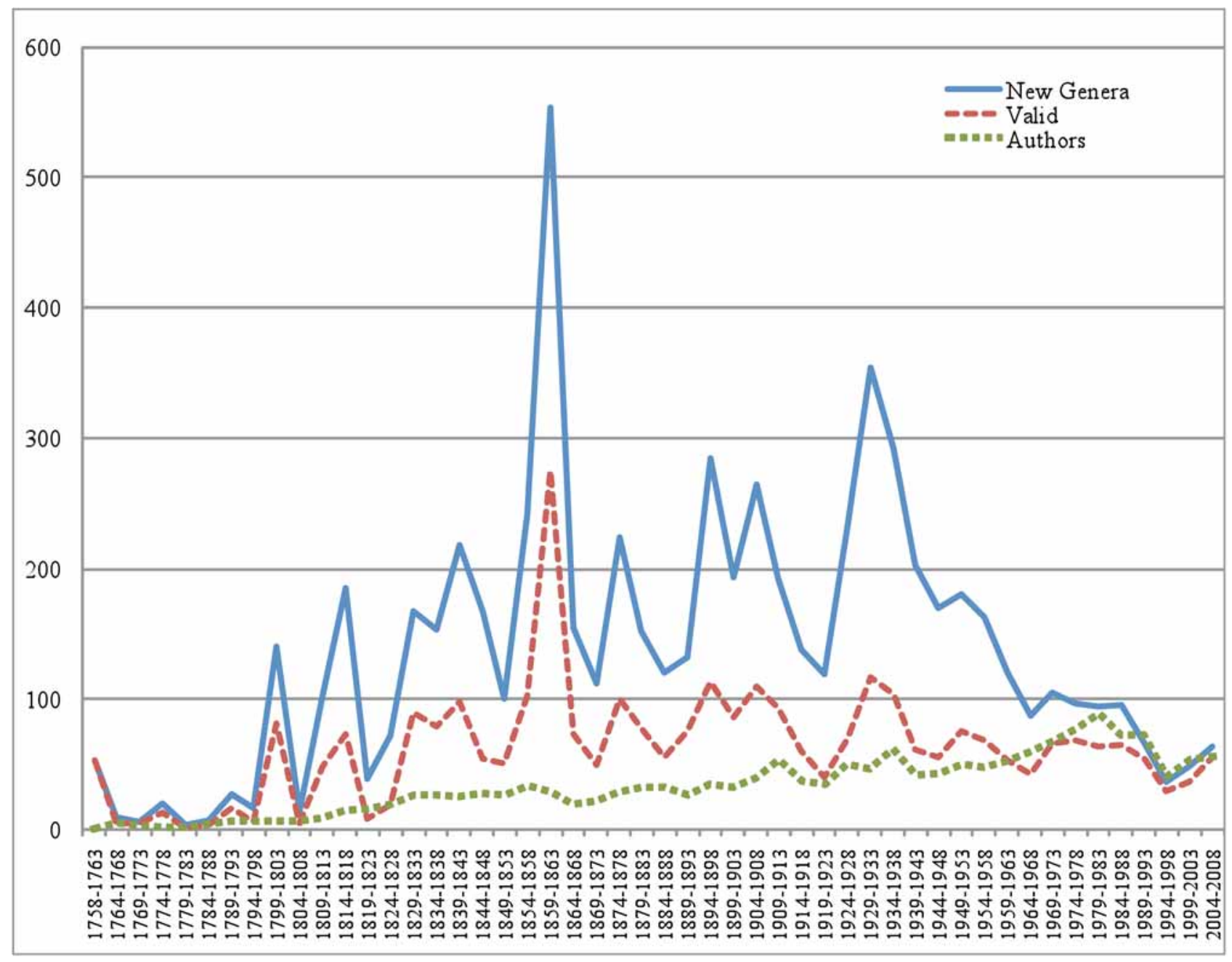

FIGURE 2. Number of new marine genus-level taxa (genera and subgenera) of marine fishes, number of names considered to be valid (as genera), and number of authors, per 5-year periods.

The average genus of marine fishes contains 5.4 species recognized as valid. [For comparison, the average number of species in freshwater fish genera is 6.7, where the largest genera are Barbus (314 species), Haplochromis (205), Schistura (177), Corydoras (153), Etheostoma (149), Puntius (133), Trichomycterus (133), Hypostomus (129), Rivulus (129) and Synodontis (128).] Some of these genera probably will be split into additional genera, and splitting for some has already been suggested, especially as a result of molecular genetic analyses. The "size" of genera presumably represents evolutionary history and success, but also is determined by historical consensus among fish taxonomists. However, the success in defining monophyletic groups for most marine taxa has not yet been tested.

Does the current description of new genera reflect a splitting of existing taxa or the discovery of completely new biodiversity? Molecular and morphological studies using new techniques result in some splitting, and less so the lumping of existing genera as an effort is made to identify monophyletic groups. At the same time, description of new genera representing new biodiversity discoveries continues. One way to distinguish between the two is to examine the type species of the new genera-is the type species of the newly-named genus a new species, indicating new generic diversity discovery? Or was the new genus established for a previously described species that has been moved to the new genus? This is somewhat of a generalization because a new genus may contain both a previously described species and one or more new species, and the type species selected may represent one of the previously described species. 
TABLE 5. Number of described and valid marine genus-level taxa (genera and subgenera) published by the 25 most prolific authors, from 1758 through 2009, with the percentage valid (as genera) per author and the year of their first publication.

\begin{tabular}{llllll}
\hline Rank & Author & Described & Valid & $\%$ Valid & First Publication \\
\hline 1 & Jordan D. S. & 496 & 177 & 35.69 & 1877 \\
2 & Gill T. N. & 420 & 214 & 50.95 & 1858 \\
3 & Whitley G. P. & 388 & 112 & 28.87 & 1927 \\
4 & Fowler H. W. & 329 & 79 & 24.01 & 1901 \\
5 & Bleeker P. & 294 & 161 & 54.76 & 1845 \\
6 & Günther A. & 204 & 131 & 64.22 & 1859 \\
7 & Cuvier G. & 168 & 89 & 52.98 & 1798 \\
8 & Evermann B. W. & 166 & 45 & 27.11 & 1887 \\
9 & Smith J. L. B. & 165 & 70 & 42.42 & 1931 \\
10 & Swainson W. & 134 & 49 & 36.57 & 1838 \\
11 & Rafinesque C. S. & 122 & 46 & 37.7 & 1810 \\
12 & Gilbert C. H. & 117 & 62 & 52.99 & 1879 \\
13 & Lacepède B. G. E. & 111 & 68 & 61.26 & 1798 \\
14 & Regan C. T. & 110 & 58 & 52.73 & 1903 \\
15 & Kaup J. J. & 107 & 45 & 42.06 & 1826 \\
16 & Hubbs C. L. & 90 & 25 & 27.78 & 1915 \\
17 & Bean T. H. & 72 & 47 & 65.28 & 1879 \\
18 & Valenciennes A. & 72 & 34 & 47.22 & 1830 \\
19 & Ogilby J. D. & 72 & 24 & 33.33 & 1885 \\
20 & Herre A. W. C. T. & 62 & 14 & 22.58 & 1923 \\
21 & Goode G. B. & 61 & 37 & 60.66 & 1879 \\
22 & Starks E. C. & 60 & 32 & 53.33 & 1895 \\
23 & Castelnau F. L. & 58 & 16 & 27.59 & 1855 \\
24 & Snyder J. O. & 57 & 20 & 35.09 & 1900 \\
25 & Linnaeus C. & 56 & 55 & 98.21 & 1758 \\
\hline & & & & &
\end{tabular}

Numbers of new marine genera described in combination with new species descriptions for the last 51 years are shown in Table 6. Note that the number of genera described for 10-year periods shows a decrease in the description of new marine genera with a new species as the type species of the genus.

Marine species by selected family. Marine fish families fall into several groups, although some fishes of some families are in more than one category: commercial families with large species, commercial families with small to medium-sized species, and families of no commercial value and/or with small species, or species which are difficult to catch. Some families have large species (usually widespread) that have been described numerous times (note percent valid in the table), especially ones with large changes with growth (such as ocean sunfishes, with 47 names for four valid species). We can distinguish 'mature families' (those with few new species in the last 10 years) from 'active families', those with new species now being found and described. A list of all fish families/subfamilies through Feb. 19, 2010 (showing available names, valid names, and new species in the last 10 years) is presented at http://www.calacademy.org/research/ichthyology/ catalog/SpeciesByFamily.asp. Table 7 shows data for selected marine fish families. The first four families contain moderate to large species, most of which have wide ranges and are commercially important. The next nine families/subfamilies are small and/or hard to collect. Gobiidae and Cottidae contain some freshwater species which have been excluded. 


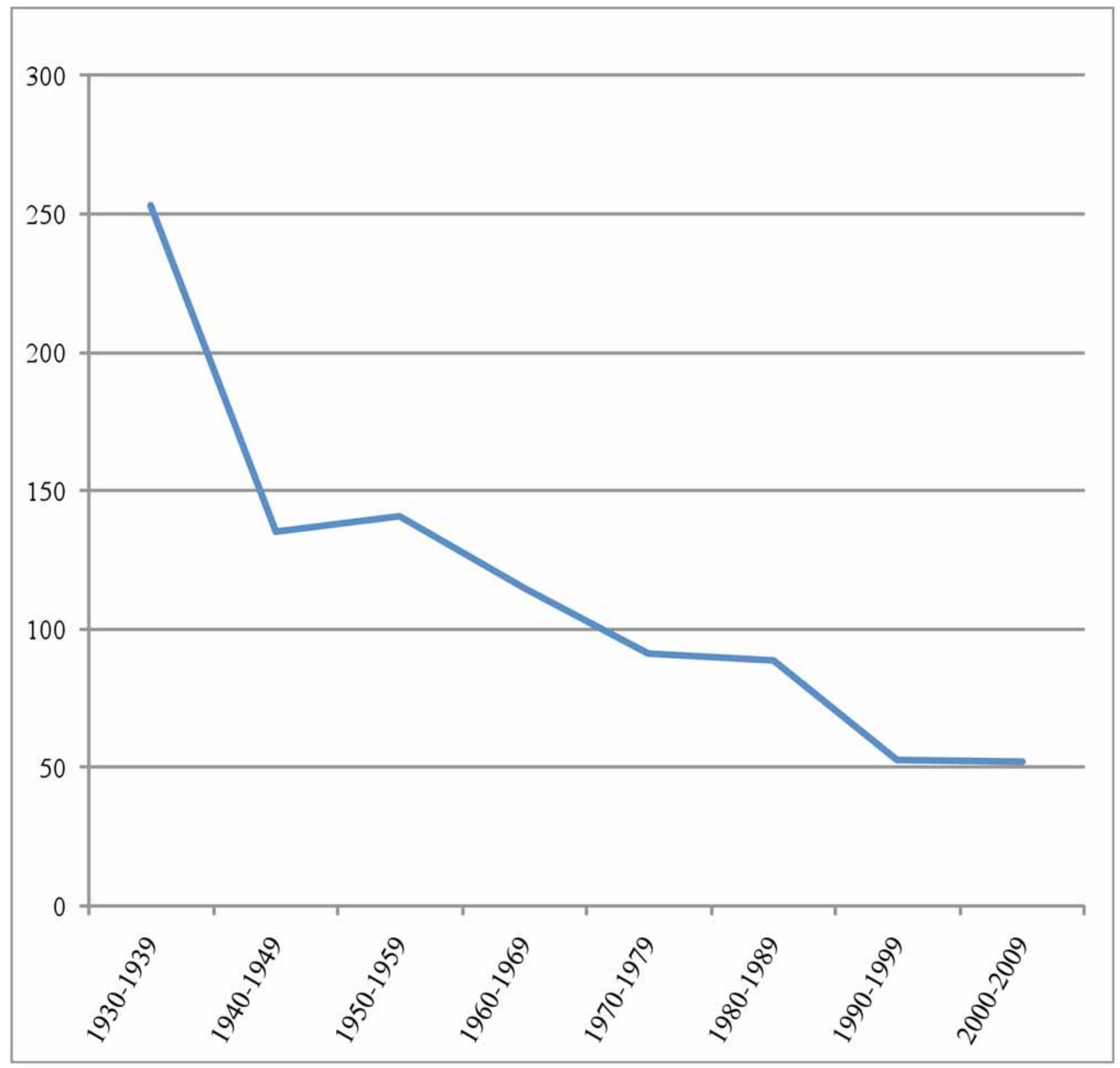

FIGURE 3. Number of currently valid marine genus-group taxa (genera and subgenera) described in combination with new species from 1929 through 2009, by 10-year periods.

We can assess the depth of capture of new species of selected coral/rocky reef families in the last 20 years, although the discovery of deeper-living species is just beginning. This shows (Table 8) that new species are generally being collected in greater depths, thereby reflecting the more complete sampling of shallow-reef species (except for species in some families containing small species).

New marine families. New macro-biodiversity discoveries can be defined as new families that are based on discovery of a unique and unusual new genus. These are distinguishable from new families that result from splitting or reorganizing of existing genera and species through phylogenetic studies. Most of the families of fishes and much of the major biodiversity were discovered and named before 1900. There is no database for fish families. Are we currently finding new and unusual taxa or have we discovered the unusual fish evolutionary innovations? To our knowledge, in the last 50 years, there have been only eight recognized new marine families described based on new biodiversity discoveries (about 1.6\% of total fish families currently recognized). 
TABLE 6. Number of new marine genus-level taxa (genera and subgenera) described in combination with descriptions of new species as the type species from 1959 through 2009 by year, and at right by 10-year periods from 1930 through 2009.

\begin{tabular}{llllllll}
\hline Year & New & Year & New & Year & New & Years & \\
\hline 1959 & 19 & 1976 & 12 & 1993 & 8 & & \\
1960 & 11 & 1977 & 12 & 1994 & 6 & & \\
1961 & 14 & 1978 & 18 & 1995 & 4 & & 253 \\
1962 & 6 & 1979 & 10 & 1996 & 3 & $1930-1939$ & 135 \\
1963 & 9 & 1980 & 8 & 1997 & 4 & $1940-1949$ & 141 \\
1964 & 10 & 1981 & 8 & 1998 & 3 & $1950-1959$ & 91 \\
1965 & 15 & 1982 & 9 & 1999 & 4 & $1960-1969$ & 89 \\
1966 & 23 & 1983 & 14 & 2000 & 1 & $1970-1979$ & 53 \\
1967 & 14 & 1984 & 10 & 2001 & 4 & $1990-1989$ & 52 \\
1968 & 4 & 1985 & 8 & 2002 & 4 & $2000-2009$ & \\
1969 & 9 & 1986 & 6 & 2003 & 3 & & \\
1970 & 9 & 1987 & 9 & 2004 & 8 & & \\
1971 & 10 & 1988 & 7 & 2005 & 5 & & \\
1972 & 7 & 1989 & 10 & 2006 & 5 & & \\
1973 & 4 & 1990 & 8 & 2007 & 11 & & \\
1974 & 3 & 1991 & 10 & 2008 & 2 & & \\
1975 & 6 & 1992 & 3 & 2009 & 9 & & \\
\hline
\end{tabular}

TABLE 7. Number of available species-level taxa (species and subspecies) for marine fishes, their current status, and the percent valid at the species level for selected families and subfamilies for 1758-through 2009 and in the last 10 years.

\begin{tabular}{|c|c|c|c|c|c|c|}
\hline Family/Subfamily & Available & Currently valid & Synonym & Uncertain & $\%$ valid & $\begin{array}{l}\text { New last } 10 \\
\text { years }\end{array}$ \\
\hline Carangidae (Jacks and allies) & 619 & 147 & 452 & 17 & 23.75 & 2 \\
\hline Istiophoridae (Billfishes) & 61 & 10 & 49 & 2 & 16.39 & 0 \\
\hline Scombridae (Tunas and allies) & 182 & 53 & 127 & 2 & 29.12 & 0 \\
\hline Carcharhinidae (Large sharks) & 190 & 52 & 120 & 17 & 27.37 & 0 \\
\hline Gobiidae (Gobies) & 1838 & 1165 & 644 & 24 & 63.38 & 180 \\
\hline Cottidae (Sculpins) & 327 & 188 & 138 & 1 & 57.49 & 9 \\
\hline Symphurinae (Tongue soles) & 92 & 77 & 13 & 2 & 83.7 & 8 \\
\hline Ogcocephalidae (Batfishes) & 96 & 66 & 26 & 4 & 68.75 & 10 \\
\hline Callionymidae (Dragonets) & 276 & 183 & 90 & 3 & 66.3 & 17 \\
\hline Bythitidae (Livebearing brotulas) & 205 & 192 & 12 & 1 & 93.66 & 105 \\
\hline Tripterygiidae (Threefin blennies) & 207 & 167 & 39 & 1 & 80.68 & 21 \\
\hline $\begin{array}{l}\text { Syngnathidae (Pipefishes/ } \\
\text { Seahorses) }\end{array}$ & 557 & 300 & 250 & 6 & 53.86 & 29 \\
\hline Scorpaenidae (Scorpionfishes) & 331 & 209 & 112 & 10 & 63.14 & 23 \\
\hline
\end{tabular}

A surprising discovery was of the megamouth shark (Megachasma, family Megachasmidae Taylor et al. 1983), a large species that feeds by straining. It was unknown to scientists before that time; the first specimen was caught tangled in a sea anchor. The discovery of deep gaseous hydrothermal vents revealed new families 
and higher categories of invertebrates, but the only new fishes described was one species in a new genus Thermarces of a known deep-sea family Zoarcidae.

TABLE 8. Average depth of capture (in meters) of new marine species-level taxa (species and subspecies) in selected families based on data published for primary types for 1985-2009. Numbers in parentheses are numbers of species represented.

\begin{tabular}{llllll}
\hline Family & $1985-1989$ & $1990-1994$ & $1995-1999$ & $2000-2004$ & $2005-2009$ \\
\hline Apogonidae & $12.38(11)$ & $23.50(19)$ & $26.63(19)$ & $18.27(18)$ & $30.30(6)$ \\
Chaetodontidae & $28.25(2)$ & none & $30.48(1)$ & $140.00(1)$ & none \\
Gobiidae & $26.08(26)$ & $28.79(45)$ & $51.53(20)$ & $24.06(50)$ & $36.17(74)$ \\
Labridae & $25.51(15)$ & $17.21(12)$ & $26.42(34)$ & $53.69(21)$ & $33.56(14)$ \\
Pomacentridae & $34.78(15)$ & $7.57(23)$ & $9.74(10)$ & $16.05(19)$ & $45.14(11)$ \\
Pseudochromidae & $22.95(6)$ & $25.91(7)$ & $17.34(11)$ & $15.70(17)$ & $30.33(3)$ \\
Serranidae & $107.34(17)$ & $93.50(17)$ & $110.73(14)$ & $61.31(8)$ & $149.63(8)$ \\
\hline
\end{tabular}

At the same time, some very unusual bathypelagic (1000-4000 meters) families have been shown recently to be members of existing families and genera, and they are no longer recognized-a decrease in biodiversity! Kasidoroidae Robins \& de Sylva (1965) was shown by de Sylva \& Eschmeyer (1977) to be based on unusual juveniles of the family Gibberichthyidae, and Johnson et al. (2009) synonymized two families into a third. They studied transitional specimens, and based on morphological and mitogenomic sequence data, showed that fishes assigned to Mirapinnidae, Megalomycteridae and Cetomimidae were larvae, males and females, respectively, of the single family Cetomimidae.

TABLE 9. New marine families based on discoveries of new species from 1960-2009.

\begin{tabular}{|c|c|c|}
\hline Year & Family & Comments \\
\hline 1965 & Kasidoroidae & $\begin{array}{l}\text { Robins \& de Sylva (1965)—young of Gibberichthyidae (see de Sylva \& Eschmeyer } \\
\text { 1977) }\end{array}$ \\
\hline 1969 & Amarsipidae & Haedrich (1969)_aberrant stromateoid, currently valid, one genus/one species \\
\hline 1980 & Hexatrygonidae & Heemstra \& Smith (1980)—stingray with 6 gill slits, now 5 species \\
\hline 1981 & Hexatreatobatidae & Chu et al (1981) — synonym of earlier-named family Hexatrygonidae \\
\hline 1981 & Hispidoberycidae & Kotlyar (1981)—stephanoberycoid, one genus/one species \\
\hline 1983 & Megachasmidae & Taylor et al. (1983)_large shark, feeds by straining, now several specimens \\
\hline 1986 & Dinopercidae & Heemstra \& Hecht (1986)— percoid, valid, now two genera \\
\hline 2002 & Paraulopidae & Sato \& Nakabo (2002) — deep-sea aulopiform, two genera, now four species \\
\hline
\end{tabular}

Deep-reef and upper-slope areas would appear to be the major habitats where we can expect new unusual discoveries above the species level; however, this is not supported by the data (Table 9). There are no new families from deep-reef and upper-slope areas. At the generic level, Richard Pyle (pers. comm. 9/2009) reports only two potentially new genera from deep coral reef depths were discovered in recent years. Deep coral reef species are related to shallow water species occurring above them. We conclude that it is unlikely that many new families of marine fishes will be discovered.

Mid-water fish biodiversity. Midwater fishes are pelagic and are often widespread, occurring in more than one ocean. Most spend their entire life off the bottom. Many migrate each night to shallow water, such as lanternfishes (Myctophidae). Most mid-water fishes are small, less than 15-20 cm in length. Many studies on mid-water fishes were published in the 1960s-1970s, with fewer studies published in recent years. Mid-water trawls, especially closing nets, are most effective. A few, mostly benthic families contain mid-water species 
(e.g., Macrouridae, Liparidae). Mid-water fishes by selected orders or suborders show that descriptions of new taxa have declined based on comparing the last 30 years and the last 10 years (Table 10).

Deep-living mid-water species that do not migrate to shallower waters are less well known than those that can be caught near the surface at night. More new taxa are expected as deep-ocean trawling continues, but the increase in new taxa is correlated with sampling effort. A recent example (Prokofiev \& Kukuev 2007) is the revision of the swallowerfish genus Pseudoscopelus (Chiasmodontidae). The first species was described in 1892, with 7 more by 1971, and new species described in 2005 (1), 2006 (3), and 2007 (5) for a total of 17 species. Prokofiev \& Kukuev (2007) state, “.... the fauna of [chiasmodontids] of the Indo-Pacific is still poorly known." Obviously, the number of new deep mid-water species to be found is mostly dependent on trawling operations by staff employed by universities and governments.

TABLE 10. Number of available and valid species-level taxa (species and subspecies) (1758-through 2009), and number of species and subspecies described in the last 30, and last 10, years in selected families of mid-water fishes.

\begin{tabular}{|c|c|c|c|c|c|}
\hline Order & Family & Available & Valid & $\begin{array}{l}\text { Last } 30 \\
\text { Years }\end{array}$ & $\begin{array}{l}\text { Last } 10 \\
\text { Years }\end{array}$ \\
\hline \multirow[t]{4}{*}{ Saccopharyngiformes } & Cyematidae & 3 & 2 & 0 & 0 \\
\hline & Saccopharyngidae & 16 & 10 & 6 & 1 \\
\hline & Eurypharyngidae & 6 & 1 & 0 & 0 \\
\hline & Monognathidae & 15 & 15 & 9 & 0 \\
\hline \multirow[t]{4}{*}{ Stomiiformes } & Gonostomatidae & 52 & 33 & 5 & 1 \\
\hline & Sternoptychidae & 91 & 75 & 23 & 2 \\
\hline & Phosichthyidae & 29 & 24 & 6 & 0 \\
\hline & Stomiidae & 413 & 289 & 94 & 28 \\
\hline \multirow[t]{2}{*}{ Myctophiformes } & Neoscopelidae & 10 & 6 & 0 & 0 \\
\hline & Myctophidae & 395 & 250 & 31 & 10 \\
\hline \multirow[t]{11}{*}{ Lophiiformes } & Caulophrynidae & 10 & 5 & 2 & 0 \\
\hline & Neoceratiidae & 1 & 1 & 0 & 0 \\
\hline & Melanocetidae & 25 & 6 & 2 & 0 \\
\hline & Himantolophidae & 27 & 19 & 11 & 0 \\
\hline & Diceratiidae & 7 & 6 & 2 & 1 \\
\hline & Oneirodidae & 120 & 66 & 17 & 4 \\
\hline & Thaumatichthyidae & 9 & 8 & 2 & 1 \\
\hline & Centrophrynidae & 1 & 1 & 0 & 0 \\
\hline & Ceratiidae & 22 & 4 & 0 & 0 \\
\hline & Gigantactinidae & 28 & 23 & 16 & 1 \\
\hline & Linophrynidae & 47 & 29 & 7 & 1 \\
\hline \multirow[t]{4}{*}{ Stephanoberyciformes } & Stephanoberycidae & 5 & 4 & 1 & 1 \\
\hline & Hispidoberycidae & 1 & 1 & 1 & 0 \\
\hline & Melamphaidae & 67 & 54 & 13 & 10 \\
\hline & Gibberichthyidae & 3 & 2 & 0 & 0 \\
\hline
\end{tabular}

Indo-Pacific fauna. The highest number of marine fish species occurs in tropical areas of the Indian and western Pacific oceans east to the central Pacific, an area known as the Indo-Pacific faunal region. IndoPacific shore fishes are the subject of a classic paper by J. E. Randall (1998). Randall discussed endemism, disjunct distributions, and species versus subspecies. Another important paper, by Springer (1982), defined the Pacific Plate bioregion. Halas \& Winterbottom (2009) provided information on the origin of the East 
Indies coral reef biota, and defined the "East Indies Triangle" as islands between Sumatra in the west, New Guinea in the east, and Luzon, Philippines in the north. This area has the highest marine biodiversity, including fishes, in the world. The number of marine fish species declines with distance from this area, with 622 species in the Hawaiian Islands (Randall 2007) and 139 shore species at Easter Island (Randall \& Cea in press). Authors differ as to whether the so-called center of origin of coral reef species is the Philippines (Carpenter \& Springer 2005) or West Papua, Indonesia (Allen \& Erdmann 2009). Randall (1998) and Halas \& Winterbottom (2009) suggested causes for why the East Indian region contains the most marine species. Allen \& Erdman (2009) reported 1,511 coral reef species in 451 genera, including 26 endemic species at Bird's Head Peninsula, West Papua, Indonesia. Halas \& Winterbottom (2009) tested four mechanisms proposed for the origin of the biodiversity in the East Indies coral triangle, without finding empirical support for any one mechanism.

A sub-set of the fishes of the Indo-Pacific region is the tropical coral reef fauna. Discoveries of new coral reef species have declined, and it is difficult to find a new shallow coral reef species (Randall, pers. comm. Jan. 2010). This does not apply to a few groups containing small species, such as some families in the suborder Gobioidea (gobies and allies).

Tomio Iwamoto, a world expert on deep-sea fishes and the first author (W.N.E.) have identified areas where more work is needed, especially the Indian Ocean, deep-sea ridges and seamounts, and in deep water generally (mostly in the Southern Hemisphere). A statement in a recent paper (Iwamoto et al. 2009: 47) noted, "The recent captures in more than 3,000 m off Japan, ... are additional examples of this lack of adequate collecting at greater ocean depths." Grenadiers (Macrouridae) are Iwamoto's specialty, and he and co-workers have described 93 species in the last 39 years (through 2009); 390 species are currently recognized as valid.

Museum collections. Most type specimens and nearly all major collections of marine fishes are housed in science museums, either independent or associated with universities or governments (Table 11). These collections form the primary source of material for taxonomic studies. The museums established earliest contain the most type specimens. Museums more recently established tend to contain more holotypes and fewer syntypes. Full names for collections and more information on collections can be found in Fricke \& Eschmeyer (2010). An important historical summary of fish collections, with information on most major collections, is provided in Pietsch \& Anderson (1997) under the title "Collection Building in Ichthyology and Herpetology." Of importance to biodiversity studies, many museums have now prepared type catalogs, many type localities are now geo-referenced, and complete holdings may be online. Note however, that many specimens in large museums are misidentified or identified with an old name-now a synonym of another species. Type specimens that were presumed to be lost or missing are being found, especially at major museums such as the Natural History Museum (London). Specimens of many new taxa are in small, mostly new, regional museums. In the Catalog of Fishes online (under Ichthyological Collections) information is provided on museums containing fish specimens. Ichthyology has benefited from the easy access to specimens; there are few large private collections. Many museums reflect primarily the focus of the institution and the specialties of the curators. Type catalogs also provide historical information on individual collections. These collections contain an enormous amount of biodiversity information.

Museums serve other functions. As habitats continue to become degraded or destroyed, species become extinct, and restrictions are placed on collecting, the specimens in museums may be the only ones available for study. An important role is the housing of voucher specimens, especially for molecular genetic studies. When vouchers are not available, many conclusions made in the literature can not be verified; this is especially true for barcoding and data in GenBank.

Environmental factors and geographic areas. The most important factor in marine fish distribution is temperature, and this is why we can define families as cold-water and warm-water. After temperature, habitat is probably next-with soft-bottom continental species, reef-associated species, brackish-water species, etc.

The data support the hypothesis that the new marine species are fairly well known in some areas, but new species are abundant in other areas (Table 12). For example, there has been only two new marine species described from Canadian waters in the last 40 years, but 38 from Brazil and 90 from Japan in the last nine years. 
TABLE 11. Number of marine species and subspecies represented by primary type specimens (as of the end of 2009) in major museum fish collections.

\begin{tabular}{lllll}
\hline Rank & Abbreviation & Holotype, Lectotype, Neotype & Syntypes & Total \\
\hline 1 & USNM (Washington) & 3613 & 543 & 4156 \\
2 & BMNH (London) & 1720 & 1245 & 2965 \\
3 & MNHN (Paris) & 2025 & 731 & 2756 \\
4 & AMS (Sydney) & 855 & 267 & 1122 \\
5 & RMNH (Leiden) & 741 & 381 & 1122 \\
6 & CAS/SU (San Francisco) & 939 & 145 & 1084 \\
7 & ZMB (Berlin) & 474 & 454 & 928 \\
8 & ANSP (Philadelphia) & 725 & 84 & 809 \\
9 & MCZ (Cambridge) & 475 & 311 & 786 \\
10 & ZIN (Moscow) & 578 & 157 & 735 \\
11 & BPBM (Honolulu) & 704 & 10 & 714 \\
12 & ZMUC (Copenhagen) & 473 & 119 & 592 \\
13 & NMW (Vienna) & 185 & 290 & 475 \\
14 & SAIAB (Grahamstown) & 452 & 0 & 452 \\
15 & ZSI (Calcutta) & 229 & 150 & 379 \\
16 & SMF (Frankfurt) & 240 & 116 & 356 \\
17 & QM (Brisbane) & 233 & 57 & 290 \\
18 & WAM (Perth) & 259 & 3 & 262 \\
19 & FMNH (Chicago) & 243 & 15 & 258 \\
20 & ZUMT (Tokyo) & 209 & 18 & 227 \\
21 & ZMA (Amsterdam) & 126 & 91 & 217 \\
22 & CSIRO (Hobart) & 194 & 0 & 194 \\
23 & SIO (La Jolla) & 194 & 0 & 194 \\
24 & LACM (Los Angeles) & 186 & 0 & 186 \\
25 & SAM (Cape Town) & 129 & 55 & 184 \\
\hline
\end{tabular}

TABLE 12. Number of new marine species-level taxa (species and subspecies) described from selected geographic areas in 10-year periods. Number of species is based on their primary type locality.

\begin{tabular}{lllllll}
\hline Locality & $1950-1959$ & $1960-1969$ & $1970-1979$ & $1980-1989$ & $1990-1999$ & $2000-2009$ \\
\hline North Pacific & 12 & 6 & 22 & 24 & 8 & 24 \\
Antarctic & 2 & 15 & 11 & 25 & 11 & 12 \\
North Atlantic & 25 & 7 & 8 & 13 & 7 & 18 \\
California & 43 & 22 & 24 & 20 & 18 & 13 \\
Australia & 89 & 42 & 87 & 163 & 119 & 240 \\
New Zealand & 17 & 12 & 22 & 43 & 16 & 10 \\
Canada & 1 & 3 & 3 & 1 & 0 & 1 \\
Brazil & 12 & 20 & 18 & 12 & 10 & 38 \\
China & 11 & 35 & 29 & 78 & 23 & 26 \\
Taiwan & 12 & 26 & 16 & 23 & 26 & 43 \\
Japan & 132 & 50 & 65 & 101 & 53 & 90 \\
\hline
\end{tabular}


Basin and area analyses. We also have examined two basins and one group of islands in more detail. Significant effort was made by one of us (R.F.) to identify valid species and synonyms and endemics from these basins. Species described in the early years often had multiple and/or questionable localities. Many had general localities. For example, a Linnaeus species might have six or more sources, and one of them may have involved a Mediterranean Sea locality. If a primary type locality has never been established for the species, it is impossible to include that species with certainty as one with a Mediterranean Sea type locality. So those species are excluded from the analysis. If a species is a Mediterranean Sea endemic, and the Mediterranean Sea was one of several original localities, then that species is included.

TABLE 13. Number of new marine species-level taxa (species and subspecies), number currently valid (as species), and number of authors, in 5-year periods, from the Mediterranean Sea.

\begin{tabular}{llllllll}
\hline Years & Species & Valid & Authors & Years & Species & Valid & Authors \\
\hline $1758-1763$ & 88 & 81 & 1 & $1884-1888$ & 26 & 7 & 7 \\
$1764-1768$ & 17 & 5 & 3 & $1889-1893$ & 18 & 8 & 6 \\
$1769-1773$ & 1 & 0 & 1 & $1894-1898$ & 3 & 0 & 2 \\
$1774-1778$ & 8 & 0 & 2 & $1899-1903$ & 1 & 0 & 1 \\
$1779-1783$ & 1 & 0 & 1 & $1904-1908$ & 7 & 3 & 5 \\
$1784-1788$ & 20 & 9 & 2 & $1909-1913$ & 11 & 1 & 6 \\
$1789-1793$ & 43 & 8 & 3 & $1914-1918$ & 4 & 2 & 3 \\
$1794-1798$ & 3 & 0 & 3 & $1919-1923$ & 5 & 1 & 5 \\
$1799-1803$ & 81 & 3 & 6 & $1924-1928$ & 14 & 5 & 10 \\
$1804-1808$ & 6 & 3 & 2 & $1929-1933$ & 4 & 0 & 4 \\
$1809-1813$ & 307 & 69 & 6 & $1934-1938$ & 9 & 1 & 6 \\
$1814-1818$ & 24 & 11 & 6 & $1939-1943$ & 1 & 0 & 1 \\
$1819-1823$ & 39 & 8 & 8 & $1944-1948$ & 2 & 0 & 2 \\
$1824-1828$ & 164 & 14 & 7 & $1949-1953$ & 7 & 4 & 6 \\
$1829-1833$ & 97 & 16 & 15 & $1954-1958$ & 5 & 0 & 6 \\
$1834-1838$ & 63 & 17 & 11 & $1959-1963$ & 7 & 4 & 6 \\
$1839-1843$ & 69 & 6 & 12 & $1964-1968$ & 5 & 2 & 3 \\
$1844-1848$ & 52 & 9 & 11 & $1969-1973$ & 9 & 3 & 8 \\
$1849-1853$ & 23 & 4 & 8 & $1974-1978$ & 3 & 3 & 4 \\
$1854-1858$ & 50 & 2 & 8 & $1979-1983$ & 2 & 1 & 2 \\
$1859-1863$ & 32 & 3 & 9 & $1984-1988$ & 4 & 3 & 3 \\
$1864-1868$ & 15 & 4 & 8 & $1989-1993$ & 2 & 2 & 3 \\
$1869-1873$ & 6 & 2 & 5 & $1994-1998$ & 2 & 2 & 3 \\
$1874-1878$ & 9 & 2 & 6 & $1999-2003$ & 2 & 2 & 4 \\
$1879-1883$ & 45 & 8 & 9 & $2004-2008$ & 1 & 1 & 3 \\
\hline
\end{tabular}

The Mediterranean Sea. The Mediterranean Sea is an extension of the northeastern Atlantic Ocean, connected through the Strait of Gibraltar. In the northeast, there is an extension of the Mediterranean Sea-the Black Sea with the Sea of Azov, connected through the Dardanelles, the Sea of Marmara and the Bosporus. The present treatment deals only with the Mediterranean Sea proper. The Mediterranean Sea is about 3,730 $\mathrm{km}$ long, at its widest point $1,770 \mathrm{~km}$ wide, and has a surface area of approximately 2.5 million $\mathrm{km}^{2}$. Its deepest point is at 5,267 meters.

The Mediterranean Sea has a warm temperate fauna, reaching from $45^{\circ} 45^{\prime} \mathrm{N}$ (in the Gulf of Trieste) to $30^{\circ} 16^{\prime} \mathrm{N}$ (Gulf of Sidra, Libya). The climate does not support the growth of reef-building corals, so the shore 
habitats are mainly dominated by rocks, sand, and seagrass and algae beds. The large deep-sea basins of the western and eastern Mediterranean Sea contain a depauperate, in a small part endemic, deep-sea fish fauna. Due to considerable evaporation and limited freshwater inflow, the salinity is higher than in the adjacent northeastern Atlantic Ocean, especially in the eastern parts. Geologically, the Mediterranean Sea was connected to the Indian Ocean as part of the Tethys Sea in the past, so it has in part a relict fauna of Indo-West Pacific origin. The connection closed ca. 18 million years ago. Later, during the Messinian salinity crisis of 56 million years ago, the entrance through the Strait of Gibraltar was blocked by a collision of continental plates; the sea water evaporated, and the Mediterranean was reduced to large hyper saline lakes which were uninhabited by fishes. The present-day fish fauna survived in the adjacent Atlantic or the Black Sea, and immigrated after the end of that event. The temporary isolation of fish populations resulted in a relatively high percentage of endemic species (41) with an endemism rate of $7.3 \%$ (of 563 species); the total number of species is 646 with the 82 Red Sea immigrants included.

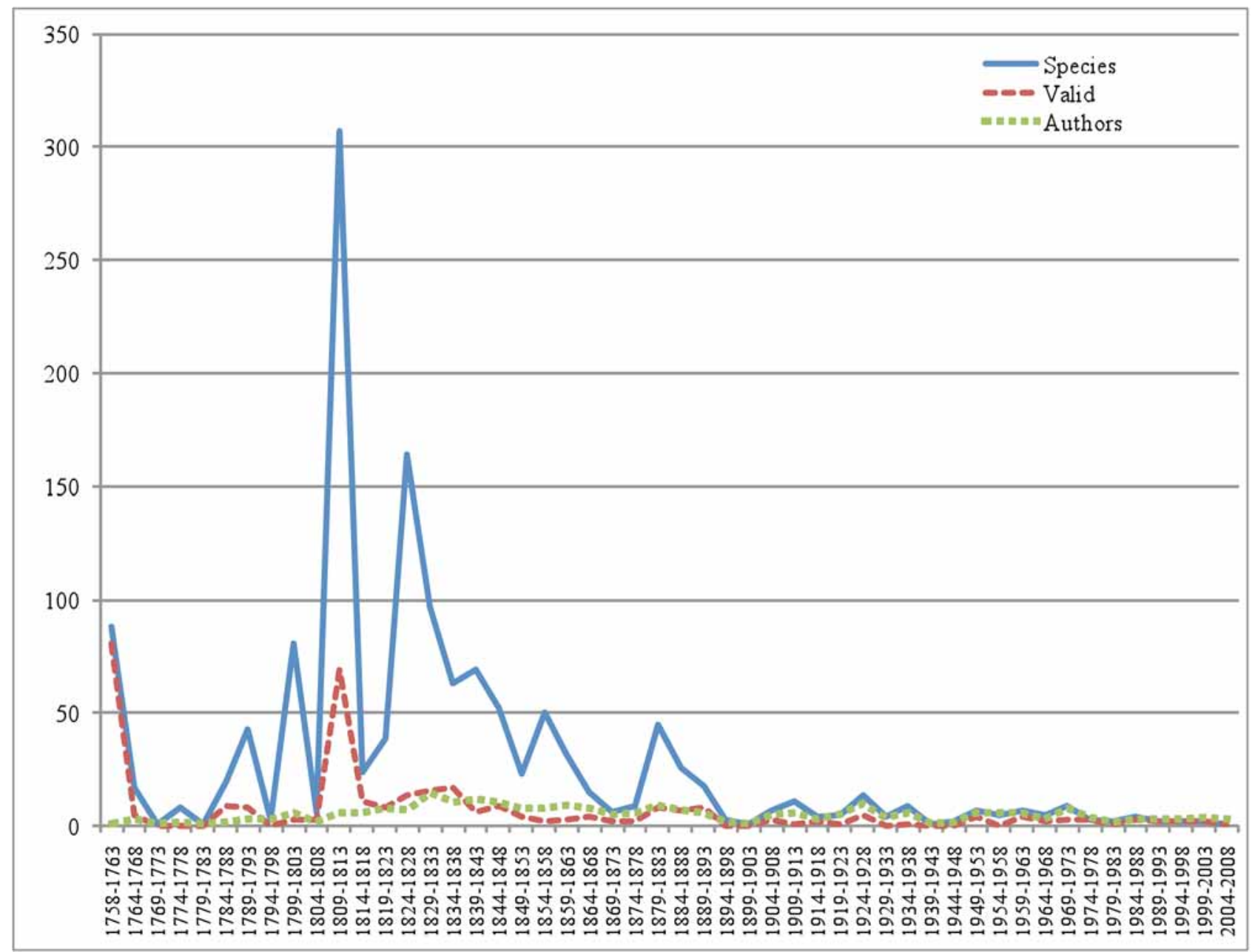

FIGURE 4. Number of new marine species-level taxa (species and subspecies), number currently valid (as species), and number of authors, in 5-year periods, from the Mediterranean Sea.

In 1869, the man-made Suez Canal was opened, connecting the Mediterranean Sea with the Red Sea as a sea-level waterway. It extends from Port Said (southeastern Mediterranean Sea) to Suez (northern Gulf of Suez, Red Sea), and its depth does not exceed 200 meters. The dominant current through the Suez Canal is southbound, but only a few Mediterranean fish species (perhaps 15) migrated to the Red Sea, while a larger number of species (about 80) occurring in the Red Sea immigrated against the current to the Mediterranean Sea (Golani 1998, Galil 2008, Mavruk \& Avsar 2008). 
The fish fauna of the Mediterranean Sea has been known for a long time. Aristotle (384-322 B.C.) was the first to study fishes at Lesbos Island (Greece), and published a natural history (Aristoteles 1454, Latin translation). Through the Middle Ages there was little research, but in the Renaissance period two important works dealing with marine fishes were published, Rondelet (1554, southern France) and Salviani (1558, Rome, Italy). The history of knowledge on Mediterranean Sea fishes was summarized by Artedi (1738); Artedi's monograph was used as a major source for formally naming fish species by Linnaeus (1758). During a Danish Expedition to the Mediterranean Sea and Red Sea, Forsskål (1775) described fish species from France, Malta, Turkey and Egypt observed in 1761-1762 (Fricke 2008). In the early 19th century, several important works dealt with marine fishes of the Mediterranean (Rafinesque 1810, Risso 1810, 1827). Later, Mediterranean fishes were included in the worldwide fish catalogs by Cuvier \& Valenciennes (1828-1850) and Günther (1859-1870). The first comprehensive modern treatment of the ichthyofauna of the Mediterranean was by Hureau \& Monod (1973), later published as an illustrated catalogue with distribution maps by Whitehead et al. (1984-1986). In a checklist of the fishes of Turkey, 367 native marine species were reported from the Mediterranean (plus 41 Red Sea immigrants) (Fricke et al. 2007). Iglesias (2009a, 2009b) recently started to establish a preliminary catalogue on Northeastern Atlantic and Mediterranean Sea fishes, which is available only as an electronic publication.

New species described from the Mediterranean Sea over time are shown in Table 13 and Figure 4. Very few new species have been discovered in the Mediterranean since about 1900, with an average of one to three new species per year since 1974. Major peaks reflect the collections described by expeditions and researchers discussed above.

The Red Sea. The Red Sea is a marine water body, an extension of the northwestern Indian Ocean, connected through the Bab el Mandeb. In the north, there are two branches, the relatively shallow Gulf of Suez and the deep Gulf of Aqaba. The Red Sea is part of the Great Rift Valley; it is about 2,200 km long, at its widest point $355 \mathrm{~km}$ wide, and has a surface area of approximately $438,000 \mathrm{~km}^{2}$.

The Red Sea has a tropical fauna; as it reaches north to $30^{\circ} \mathrm{N}$, it is the world's northernmost tropical sea. The shore fish fauna is limited to narrow fringing reefs along most of the shorelines, except for extensive sand and mud bottoms in the north (Gulf of Suez) and south. The main Red Sea and the Gulf of Aqaba contain a depauperate fish fauna, including endemic deep-sea species. Due to heavy evaporation and nearly no freshwater inflow, the salinity is higher than in the Indian Ocean, especially in the northern parts. The Red Sea was probably temporarily isolated from the Indian Ocean during glacial periods. This resulted in a high percentage of endemic species (159 species, endemism rate 13.6\%). Isolation of the fauna probably occurred at least twice (Winterbottom 1985) so there appear to be two periods of endemism. The total number of Red Sea species of fishes numbers 1,188, including 15 immigrants from the Mediterranean Sea.

The peaks in Figure 5, based on data in Table 14, reflect collecting expeditions in the Red Sea (for history see Fricke 2008). The marine fish fauna was mostly unknown before a Danish expedition with Peter Simon Forsskål as naturalist (1732-1763). He collected fish specimens mainly in Saudi Arabia and Yemen, which were posthumously described by Forsskål (1775). In the 19th century, personnel from three German museums explored the fish fauna of the Red Sea. The Berlin museum (ZMB) sent Friedrich Wilhelm Hemprich (17961825) and Christian Gottfried Ehrenberg (1795-1876) who collected specimens which were later described by Cuvier \& Valenciennes (1828-1850). The Senkenberg Museum in Frankfurt (SMF) received specimens collected by Eduard Rüppell (1794-1884) which were described by Rüppell (1828-1830, 1835-1838). Later, the Stuttgart museum (SMNS) sent Martin Theodor von Heuglin (1824-1876) and Carl Benjamin Klunzinger (1834-1914) to the Red Sea; Klunzinger described several new fish species and published the first catalogue of Red Sea fishes (Klunzinger 1870, 1871, 1884). More recently, Red Sea fish checklists were published by Dor (1984) and Goren \& Dor (1994), the latter listing 1,248 fish species as valid. Subsequently, several additional species were recorded (e.g. Randall 1994, Khalaf \& Zajonz 2007), or described as new. A recent updated checklist is Golani \& Bogorodsky 2010.

The Mascarene Islands. The Mascarenes are a group of volcanic and coralline islands in the southwestern Indian Ocean, east of Madagascar. The three main islands are Réunion (an overseas Département of France), Mauritius and Rodrigues (both part of the Republic of Mauritius). The Mascarene 
fish fauna was listed by Fricke (1999; for history see p. 4-6). The Mascarenes were first discovered by Portuguese in search of fresh water and food supplies on the route to India, and then ruled by France since 1638 (Mauritius was given to Britain in 1814). The most important early explorer of the islands was Philibert Commerson (1727-1773), who participated in Bougainville's expedition around the world in 1766-1768, and then stayed in Mauritius, where he died in 1773. Commerson described and illustrated numerous Mascarene fishes; the manuscripts were sent to Paris, where the fish species were posthumously described by Lacepède (1798-1803) and Cuvier \& Valenciennes (1828-1850). Regional checklists were published by Heemstra et al. (2004, Rodrigues) and Fricke et al. (2009, Réunion). Fish species occurring at the Mascarenes have both continental and insular Western Indian Ocean relations. A total of 1,183 species occur in the Mascarenes; 45 species are endemic (3.4\%). New species described from the Mascarene Islands over time are shown in Table 15 and Figure 6. The peaks in Figure 6 mainly represent (from left to right) descriptions by Lacepède ('1800 peak'), Bennett and Cuvier \& Valenciennes ('1833 peak'), Günther ('1863 peak'), Bleeker, Sauvage and Bliss ('1883 peak'). The '1963 peak' mainly represents French explorations in Réunion. Recent descriptions are due to SCUBA diving explorations and rotenone collections.

TABLE 14. Number of new marine species-level taxa (species and subspecies), number currently valid (as species), and number of authors, in 5-year periods, from the Red Sea.

\begin{tabular}{llllllll}
\hline Years & Species & Valid & Authors & Years & Species & Valid & Authors \\
\hline $1758-1763$ & 2 & 2 & 1 & $1884-1888$ & 20 & 7 & 3 \\
$1764-1768$ & 0 & 0 & 0 & $1889-1893$ & 2 & 1 & 2 \\
$1769-1773$ & 0 & 0 & 0 & $1894-1898$ & 5 & 4 & 1 \\
$1774-1778$ & 128 & 89 & 2 & $1899-1903$ & 5 & 2 & 4 \\
$1779-1783$ & 1 & 0 & 1 & $1904-1908$ & 1 & 0 & 1 \\
$1784-1788$ & 6 & 0 & 1 & $1909-1913$ & 0 & 0 & 0 \\
$1789-1793$ & 17 & 4 & 2 & $1914-1918$ & 4 & 4 & 2 \\
$1794-1798$ & 2 & 1 & 1 & $1919-1923$ & 1 & 1 & 1 \\
$1799-1803$ & 25 & 0 & 4 & $1924-1928$ & 15 & 5 & 1 \\
$1804-1808$ & 0 & 0 & 0 & $1929-1933$ & 5 & 2 & 1 \\
$1809-1813$ & 0 & 0 & 0 & $1934-1938$ & 4 & 2 & 6 \\
$1814-1818$ & 4 & 0 & 2 & $1939-1943$ & 3 & 2 & 2 \\
$1819-1823$ & 0 & 0 & 0 & $1944-1948$ & 0 & 0 & 0 \\
$1824-1828$ & 21 & 11 & 3 & $1949-1953$ & 8 & 5 & 7 \\
$1829-1833$ & 139 & 64 & 6 & $1954-1958$ & 16 & 4 & 9 \\
$1834-1838$ & 124 & 56 & 3 & $1959-1963$ & 8 & 7 & 4 \\
$1839-1843$ & 30 & 4 & 4 & $1964-1968$ & 14 & 9 & 10 \\
$1844-1848$ & 8 & 1 & 4 & $1969-1973$ & 20 & 13 & 19 \\
$1849-1853$ & 2 & 0 & 3 & $1974-1978$ & 34 & 25 & 18 \\
$1854-1858$ & 6 & 2 & 2 & $1979-1983$ & 39 & 32 & 25 \\
$1859-1863$ & 4 & 0 & 2 & $1984-1988$ & 25 & 25 & 21 \\
$1864-1868$ & 4 & 0 & 3 & $1989-1993$ & 12 & 12 & 16 \\
$1869-1873$ & 69 & 27 & 4 & $1994-1998$ & 12 & 11 & 10 \\
$1874-1878$ & 20 & 4 & 4 & $1999-2003$ & 8 & 8 & 9 \\
$1879-1883$ & 4 & 0 & 2 & $2004-2008$ & 6 & 6 & 10 \\
\hline
\end{tabular}




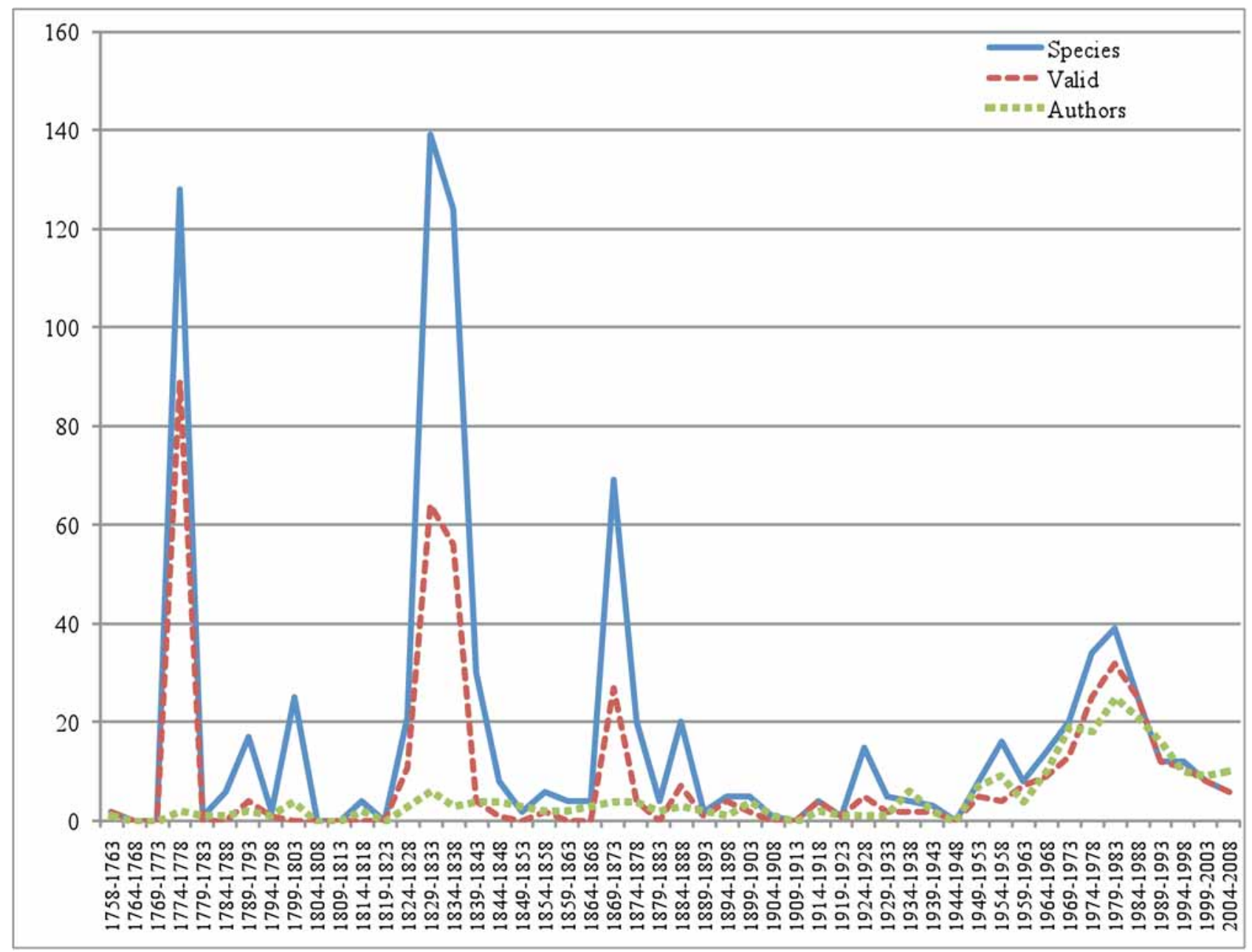

FIGURE 5. Number of new marine species-level taxa (species and subspecies), number currently valid (as species), and number of authors, in 5-year periods, from the Red Sea.

Endemism. The concept of endemism as used here is a traditional use in descriptive biodiversity-a geographical area with taxa (typically species, or genera and species) that occur only in that area. It is generally assumed that the taxa evolved there. Considerations of ancestral species, of extinctions, range contractions and expansions that may have occurred are not addressed. Phylogenetic hypotheses for numerous clades usually are not available to corroborate congruent patterns of distribution to test for vicariance or dispersal. A more rigorous cladistic approach is suggested by Harold \& Mooi (1994).

In marine fishes, endemic genera have received less attention than other taxonomic groups, and they are typically not mentioned in faunal studies. On the Biodiversity Hotpots website of Conservation International under "endemic genera" (http://www.biodiversityhotspots.org/, accessed 25 Jan. 2010), it is stated that "When assessing biodiversity data, it is important to consider not only species distributions but also distribution of higher taxa." On that site they provide a table of endemic genera from selected geographic areas for plants, mammals, birds, reptiles, amphibians and freshwater fishes. They concluded that, "Unsurprisingly though, regions with high species endemism also have greater levels of endemic genera." That conclusion is not supported by marine fish insular faunas, such as those of Easter Island, the Galapagos Archipelago, the Mascarenes and the Hawaiian Islands, but it is supported by continental areas, such as southern Africa and southern Australia. Typically, island groups or small coastal areas are used for assessing endemism in marine species. The presence of endemic genera (and species) involves many complex issues, such as geological age of the island group or coastal area, its isolation and location, arrival of ancestral progenitors, competition, suitable habitat, and environmental stability over time. 
TABLE 15. Number of new marine species-level taxa (species and subspecies), number currently valid (as species), and number of authors, in 5-year periods, from the Mascarene Islands.

\begin{tabular}{|c|c|c|c|c|c|c|c|}
\hline Years & Species & Valid & Authors & Years & Species & Valid & Authors \\
\hline $1758-1763$ & 0 & 0 & 0 & 1884-1888 & 3 & 2 & 1 \\
\hline 1764-1768 & 0 & 0 & 0 & 1889-1893 & 22 & 1 & 3 \\
\hline 1769-1773 & 1 & 1 & 1 & 1894-1898 & 1 & 0 & 1 \\
\hline 1774-1778 & 0 & 0 & 0 & 1899-1903 & 4 & 1 & 2 \\
\hline 1779-1783 & 0 & 0 & 0 & 1904-1908 & 2 & 0 & 1 \\
\hline 1784-1788 & 3 & 1 & 1 & 1909-1913 & 1 & 0 & 1 \\
\hline 1789-1793 & 1 & 0 & 1 & 1914-1918 & 5 & 1 & 2 \\
\hline 1794-1798 & 3 & 3 & 1 & 1919-1923 & 2 & 2 & 1 \\
\hline 1799-1803 & 72 & 31 & 4 & 1924-1928 & 1 & 0 & 2 \\
\hline 1804-1808 & 5 & 0 & 3 & 1929-1933 & 1 & 0 & 2 \\
\hline 1809-1813 & 0 & 0 & 0 & 1934-1938 & 2 & 1 & 2 \\
\hline 1814-1818 & 3 & 1 & 2 & 1939-1943 & 0 & 0 & 0 \\
\hline 1819-1823 & 2 & 2 & 2 & 1944-1948 & 1 & 0 & 1 \\
\hline 1824-1828 & 21 & 9 & 6 & 1949-1953 & 3 & 1 & 2 \\
\hline 1829-1833 & 118 & 51 & 8 & 1954-1958 & 2 & 0 & 1 \\
\hline 1834-1838 & 46 & 16 & 9 & 1959-1963 & 10 & 3 & 5 \\
\hline 1839-1843 & 45 & 14 & 6 & 1964-1968 & 3 & 2 & 2 \\
\hline 1844-1848 & 8 & 2 & 3 & 1969-1973 & 1 & 1 & 1 \\
\hline 1849-1853 & 3 & 1 & 3 & 1974-1978 & 12 & 12 & 10 \\
\hline $1854-1858$ & 11 & 4 & 2 & 1979-1983 & 8 & 8 & 9 \\
\hline 1859-1863 & 33 & 10 & 4 & 1984-1988 & 5 & 5 & 6 \\
\hline 1864-1868 & 8 & 3 & 5 & 1989-1993 & 4 & 4 & 6 \\
\hline 1869-1873 & 8 & 2 & 4 & 1994-1998 & 7 & 7 & 8 \\
\hline 1874-1878 & 16 & 5 & 8 & 1999-2003 & 11 & 10 & 10 \\
\hline 1879-1883 & 27 & 9 & 4 & 2004-2008 & 7 & 7 & 6 \\
\hline
\end{tabular}

For the coastal area of southern Australia (Victoria to southern Western Australia), it is suggested here (W.N.E.) that this area of reasonable size has the highest number of endemic marine fish genera anywhere (over 50)-this constitutes a marine hotspot; it is also rich in endemic species (see Gomon, et al. 2008). In the broad Indo-West Pacific tropical fauna, there are relatively few restricted endemic genera because most genera are now widespread. For marine fishes, we have counts of endemic genera of selected island groups (authority in brackets): Hawaiian Islands [Randall, Mundy] (1 genus), Fiji [Greenfield] (0), Mediterranean Sea basin [this study] (5), Red Sea basin [this study] (4), Easter Island [Randall] (1), Mascarenes [this study] (1), Galapagos Archipelago [McCosker] (1), southern Africa [Heemstra] (36). Our count of southern Australian endemic genera is over 50, with additional "non-endemic" genera having representatives in New Zealand or northern areas of Australia (counted from Gomon et al. 2008). The area extends from Victoria to southern Western Australia. South Africa is more complex with important considerations of ocean currents and water temperature, but marine endemic genera in South Africa (Namibia around to Beira Mozambique) number 36 (P. Heemstra, pers. comm., 26 Jan. 2010, and see Heemstra \& Heemstra 2004). New Zealand is another area with many endemic genera and species.

A very detailed analysis of the Australian fish fauna was published in 2006 (Hoese \& Paxton 2006). The total fish fauna in 2006 was about 4,500 described species (all habitats), and overall, 24\% of the Australian fish fauna was endemic, with substantial new discoveries still anticipated. 


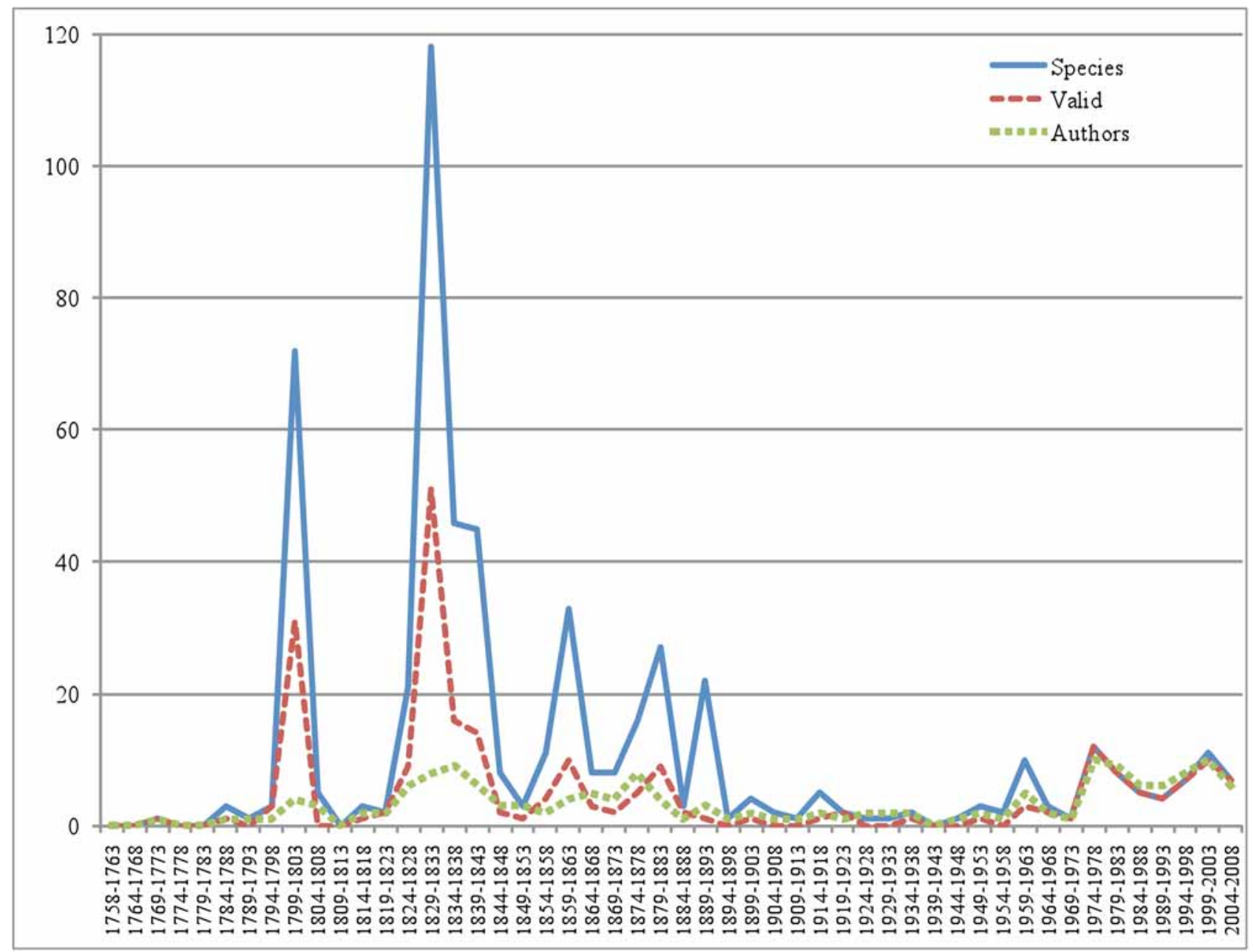

FIGURE 6. Number of new marine species-level taxa (species and subspecies), number currently valid (as species), and number of authors, in 5-year periods, from the Mascarene Islands.

For endemic marine species, there have been estimates for certain island groups and areas, but the criteria used vary - such as distance from shore, depth of capture, or the exclusion of widespread pelagic species or deep-sea species that may be found near shore. An approximation for shallow water species is about 12 to $20 \%$ endemic species in such isolated areas as the Galapagos Archipelago, Hawaiian Islands and Easter Island. The number of endemic species is low in less isolated areas, such as Fiji with 15 (Greenfield, pers. comm., 1/27/2010) and a large majority of marine Indo-Pacific tropical reef species are widespread. Species living on mud bottom areas, for example, are often not as widespread.

There is a temperate Southern Ocean fauna of mostly mobile species, with many occurring in Southern Africa, southern Australia and the southern end of South America and southern islands. The fauna off Chile is not well known, but is not extensive, partly because of its extreme southern location and lack of suitable currents, and it also reflects insufficient ichthyological exploration. Eschmeyer \& Hureau (1971) showed that the eastern Pacific tropical area was a major barrier (nearly 100\%) for movement of temperate faunas across the eastern Pacific tropics, however they noted that one to three species of the North Pacific genus Sebastes and a poacher (family Agonidae) crossed the tropics to Peru and Chile, and their closest relatives appeared to be the most southern-living species in the North Pacific off California and Mexico. It was suggested that this was a fairly recent extreme anomaly of short duration, allowing minimal crossing by some fishes and invertebrates. Movement of the Southern Ocean fauna in an easterly or westerly direction is facilitated by a stable temperature regime and strong currents. Eschmeyer \& Poss (1976, fig. 10) showed that if the 20 degree isotherm shifted to the present 25 degree isotherm during a glacial period, a significant number of islands and near-surface seamounts were available as "stepping stones" across the south Pacific. 
Contribution of molecular studies to biodiversity knowledge of marine fishes. Most fishes have many external characters useful in taxonomy. It appears that most marine species (especially larger ones and adults) are defined accurately, based on different researchers reaching the same conclusions and with consensus over time. DNA studies are used in marine fish taxonomy for two primary purposes: defining higher categories and relationships of taxa and defining species and populations. Of particular interest here are studies that reveal biodiversity at the species level.

Molecular studies can be useful to evaluate color differences between populations that are otherwise indistinguishable morphologically. Molecular studies clearly are useful in discovering species that, after investigation, may have demonstrable morphological differences. Colborn et al. (2001) showed the worldwide bonefish (genus Albula) actually to be composed of several species. There are other warm-water widespread non-reef species that are good candidates for molecular study, such as carangids. See also Zemlak et al. (2009).

Many molecular studies could be mentioned, but Baldwin et al. (2009b) is an excellent representative study. They reviewed the western Atlantic species of marine Coryphopterus, a genus containing small species, many of which are similar to one another. The study was conducted in Belize, were nearly all the species occurred. They collected fresh specimens, and took digital color photographs of young and adult specimens. DNA barcoding (mitrochondrial cytochrome c oxidase I [COI] sequences) revealed distinct genetic lineages. They used neighbor-joining trees and genetic distance matrices. Specimens were deposited in the U. S. National Museum, and DNA samples were placed in GenBank. They stated (p. 134), "Resolving the identities of many Caribbean Coryphopterus in the absence of the DNA data would have been extremely difficult." Morphological characters and color differences were used to define the species. Two of the authors had classical training in systematic ichthyology. A carefully-prepared key to the western Atlantic species was provided. Using these techniques, they synonymized one recently-described species and provided justification for recognizing up to three others. They did not discover any new species, but defined 12 valid species. Often, there are names that are available for species that were regarded as synonyms but are now regarded as valid species; that knowledge increases biodiversity valid species counts but not new species taxa. More information on barcoding and the "Barcode of Life" project can be found at www.fishbol.org/ www.barcodinglife.org.

A second use of the barcode approach in marine fishes is to confirm species identification, especially of early life history stages (see Baldwin et al. 2000a). In the six species studied, identification of larvae and juveniles was problematic because characters used to distinguish similar adults were absent or incomplete in young stages. Using barcode techniques along with chromatophore patterns recorded by digital photography, they were able to link young with adults and provide new characters to distinguish the species at all life stages. Barcoding techniques are still being evaluated, and Dasmahapatra et al. (2010) suggest that DNA barcoding detects some "species" that are real and some that are not.

A recent example of a phylogenetic study at higher taxonomic levels using DNA sequence data is that of Thacker (2009); new ideas were supplemented by morphological character analysis.

Unusual fish families/subfamilies. The discovery of biodiversity also depends on the biology of fishes, and some families will show many new species. Family Liparidae: Fishes of this family occur in shallow water and in the deep sea. They are small in size (most less than $15 \mathrm{~cm}$ long). Deep-living species place their eggs inside other animals (such as bivalve mollusks). They have a few large eggs and no larval stage, so they are not limited by surface temperatures and are not transported by surface currents. Consequently, they are able to move freely in the deep sea. They have few "morphological characters" but it is assumed they are distinguished accurately. Many species are known only from type specimens. The deep-living species apparently have small ranges, but this environment is poorly collected. Many new discoveries will continue, and two of the largest genera of marine fishes are in this family. The total species in the family Liparidae that are considered as valid as of 2009 is 370, and 202 have been described since 1980. Family Ogcocephalidae (batfishes): H. Ho (pers. comm. 15 Nov. 2009) indicates that in his Ph.D. dissertation on ogcocephalids of the Indo-Pacific, valid species will number about 65, with about half being new. Ogcocephalids are peculiar, small bottom-living species occurring both in shallow and deep depths. Many tend to live on deep-sea rough 
bottom habitats that are difficult to sample. Subfamily Symphurinae (tonguesoles): The smallest and flattest of the flatfishes. They are difficult to sample and occur widely in the deepsea. Twenty species have been described in the last 20 years, and all in the genus Symphurus. Many new species are expected.

Deep-reef fishes $(\mathbf{5 0}-\mathbf{5 0 0} \mathbf{~ m})$. Deep-reef species are defined as those fishes which are associated with coral reefs and live below about 50 meters to a depth of about 500 meters; the fauna changes at about 500 meters to more deeper-living families. Richard Pyle is the most experienced person collecting fishes at these depths, currently using re-breather SCUBA technology. He suggests (pers. comm.) that assemblages on deep reefs show comparatively low distributional overlap (between different island groups and between sites within each island group).

There are many deep reef genera of fishes than can be expected to contain many new species. For example, a recent paper on species of Plectranthias (Serranidae) by Heemstra \& Randall (2009) in the western Indian Ocean, describes one new species, but it contains the surprising statement that "... most Plectranthias species are rare in fish collections, and twenty of the 45 valid species are known from only one or two specimens." The authors note that species found in depths of 20-300 meters are solitary and sedentary and live on rugged deep-reef habitats in 50 to 300 meters.

These deep-reef areas will be a significant source of new marine fish species. We do not know at this time how widespread these deep-reef species are, but many new taxa will be found, especially when new technology is available (such as collecting from one-person submersible vehicles). Also deep trapping and long-lining should be successful. Fishes from deep reefs are probably less well known than are the fishes in the deep sea.

Deep-slope fishes. Deep slope includes depths from about 50 to 1000 or more meters, but not coralassociated species. This is another area where we expect many new species to be discovered.

An example of an isolated insular fauna with deep-slope species is the Galapagos Archipelago. The Galapagos Islands are in the eastern Pacific Ocean. They are volcanic, and lie about $1000 \mathrm{~km}$ from the mainland. The two closest islands are Malpelo (450 km ENE) and Cocos (630 km NE). To the west lies the Eastern Pacific Ocean barrier. Sea temperatures and habitats vary widely. The fauna reflects primarily the species that arrived on currents. The fishes of the Galapagos Islands have been analyzed in great detail recently (McCosker \& Rosenblatt, in press), and see also Grove \& Lavenberg (1997). The addition of new deepwater species gave a total of 75 near-shore and deep-slope species that were unique to the Galapagos. They calculated that the rate of endemism was $13.6 \%$, with a total of 550 species (not including mesopelagic species). They state that the shorefishes to a depth of $60 \mathrm{~m}$ are fairly well known. Nearly half of the Galapagos fish species are shared with the Panamic fauna to the east, $15.2 \%$ are found worldwide in the tropics and 15.9 $\%$ are Indo-Pacific shore fishes. Some are recorded as vagrants. There is one putatively endemic genus. They predict that deep-slope and benthic collections below $500 \mathrm{~m}$ will make numerous remarkable discoveries.

Diving and collecting in deep-sea submersibles resulted in the discovery of 32 undescribed fish species and many new records occurring on deep slope habitats (McCosker \& Rosenblatt, in press). They collected from rocky, nearly vertical, habitats and others that are difficult to sample. They were able to collect, film, and observe from 60-1000 meters, and they adapted new techniques for poisoning, trapping and underwater hookand-line fishing. Use of submersibles has wide potential for future research, and use of this technology is discussed in some detail by McCosker \& Rosenblatt (in press).

The important unanswered question is how widespread are deep-slope species? We do not have this information, an important unknown for estimating undiscovered marine fish biodiversity.

Collecting methods. Most collecting methods have changed little over time. New methods include use of chemicals, scuba, re-breathing scuba and submersibles. Shallow water: Reef species are taken by hand, spear-guns, hand nets, etc., often with the use of immobilizing chemicals such as rotenone. Rotenone has long been the choice for reef fish collecting (Smith-Vaniz et al. 2006) but has become somewhat controversial (see Robertson \& Smith-Vaniz 2008); clove oil has recently come into use (see Robertson \& Smith-Vaniz 2010). Dynamite was sometimes used in early years. Shore collections are made by hand, from specimens washed ashore, use of small nets in association with chemicals, traps, and other methods. A variety of seines, dredges, and trawls are used. In early years, specimens were often purchased in fish markets or directly from 
fishermen. Fish market specimens still provide new species, most recently from Taiwan. Lights suspended in the water at night attract specimens that can be caught with dip-nets. SCUBA: The invention of the demand regulator by Emile Gagnan and Jacques Cousteau in 1942 was the beginning of a new era for underwater exploration. Sixty-five years later, sales of SCUBA equipment in the U.S.A. totaled \$804 million dollars. This new technology enabled marine biologists to spend long periods of time underwater collecting and observing fish in their natural habitat. Pure air easily allows divers to spend about 45 to 60 minutes at a depth of about 60 feet. "Rebreathers," using different gas mixes allow technical divers to dive very much deeper and spend longer times underwater. A closed circuit rebreather uses $100 \%$ of each breath and completely re-circulates the breathing gases. It removes the carbon dioxide that has been generated and replenishes the oxygen. Because there is no exhausting of gases there are no bubbles and virtually no noise. This is a non-invasive method of collecting fishes. Submersibles: The use of submersibles in deep slope areas is discussed in McCosker \& Rosenblatt (in press) and is treated above. Use of this gear resulted in discovery of over 30 new deep slope species at the Galapagos Islands (about 5\% of the fauna). The submersibles allow use of ichthyocides (chemicals to stun fish), moveable collecting arms, and the ability to bring specimens to the surface for study. Progress is being made on developing one-person submersibles. Traps, long-lines: Baited traps can be used effectively at deep depths; two new genera were captured recently in about $1000 \mathrm{~m}$ by this method (Matallanas 2009). Depth is apparently limited when floatation/release mechanisms are used. Longlines have long been used to collect fishes, especially wide-ranging pelagic ones for many years, and the use of deep-set near-bottom long-lines is effective for finding new species, especially sharks and rays. Trawling: Bottom and mid-water trawls are the typical way of collecting offshore species. They can be used at any depth. Mid-water nets that can be closed before retrieval provide accurate bracketed depth ranges of captures.

Specimen illustration and photography. The recording of images of new specimens in publications has changed dramatically through the years. In earliest times, especially before the early 1800 s, types were not illustrated at all or they were only shown by simple line drawings. Artists accompanied the great exploring expeditions in the mid-1800s, and paintings were often made of fresh specimens. Laboratory line drawings of high quality were the norm for expeditions and collections into the 1900s and forward. Some publications that were illustrated in color were produced by artists painting each color illustration by hand. They used one reference original so each plate differed slightly from the others. Most of these original illustrations are still available in natural history museums.

Pen-and-ink and pencil drawings, some involving special rendering surfaces, were typical from the middle 1800 s to late 1900 s. The recent use of digital cameras to illustrate specimens in lateral view has virtually obviated the need for drawings and has replaced traditional film photography for illustrating specimens. Pen-and-ink drawings are still used to show special features.

Specimen photography. Specimen photography of "live colors" was perfected by John Randall, using a technique of pinning erect the fins of specimens, usually on the evening of capture. The median fins were "painted" with formalin to "fix" them in an erect position; the pins were removed and color photographs were then taken in lateral view. Type specimens for hundreds of publications of new marine taxa in the last half of the 1900s were prepared in this way. Smaller specimens were often photographed in water-filled tanks with the specimens positioned by glass plates. Use of antioxidants to preserve color (see Waller \& Eschmeyer 1965) was successful for preserving only some colors, and freezing and reducing exposure to light are shortterm solutions only. Digital photography has virtually replaced whole specimen drawings, and current publications tend to have both posed and in situ photographs. The resolution of digital photography allows for close-up photographs of specific parts or areas of specimens.

Underwater photography. Underwater photography has simplified the work of ichthyologists and helped in the discovery of new species. Underwater photography has come far since the early Calypso camera was introduced in 1960 . This camera was the first $35-\mathrm{mm}$ self-contained underwater camera. The Calypso was conceived by Jacques Cousteau, designed by Jean de Wouters and manufactured by Atoms in France. Production was taken over by Nikon, and the camera was sold as the Nikonos. The Nikonos became a well known and accepted series of cameras. The Nikonos was not an SLR camera, and it had to be manually focused. The quality of pictures taken using these cameras was generally very poor. Housed 35-mm SLR 
cameras were a major breakthrough and enabled photographers to consistently take excellent pictures underwater. They came with the disadvantage that only 36 pictures could be taken on each dive. Processing the film was costly and normally not possible in remote locations. The advent of digital cameras has revolutionized all photography and has made underwater photography available to the masses. Digital SLR cameras in underwater housings overcome the disadvantages of film cameras. It is now possible to take in excess of 400 pictures during one dive, the number being limited more by the dive time than the technology. The results can be viewed immediately and adjustments made if necessary. Today many new species are being photographed first, identified as a potential new species and then collected. The posting of photographs on the internet by amateur divers is now an important source of information on possible new taxa, live color, and for enlarging the known ranges of species.

Preservation of specimens. Preservation of specimens has changed through time. One of the earliest methods was to prepare dried skins. Specimens were typically mounted and stuffed, often for subsequent museum display. Sometimes "half-skins" (one side of a specimen) were prepared. The use of "spirits" for preserving fishes was also used in the 1800s. The early museums (e.g., London, Vienna, Paris, Leiden) have both dried collections and spirit collections. Nearly all of the dried specimens are still available today. By the $1900 \mathrm{~s}$ and thereafter, specimens were first placed in formaldehyde [termed formalin when diluted with water] to stop all decay. Specimens were subsequently rinsed and then placed in ethyl or isopropyl alcohol for longterm storage. Additional techniques to preserve and study specimens became available more recently. Skeletons were prepared by placing a fish carcass in a dermestid colony; the insects consume the soft tissues leaving the bones free of flesh for study. Radiographs (x-rays) were useful to study internal parts. Staining bones, cartilage and nerves in different colors was possible, and this was then accompanied by digesting the muscle tissue in whole specimens (termed clearing and staining); this was initiated by Taylor (1967), and a summary of these techniques is given by Song \& Parenti (1995).

How many marine species are there? One of the goals of this analysis was to make a prediction of the marine fish biodiversity that remains to be discovered and documented. It is by analysis of the tables and graphs-and informed conjecture - that we arrive at a value. We do have fairly complete knowledge of commercial food fishes, as well as others used in commerce, such as in the aquarium hobbyist trade. We know most of the dominant shore species, and we have a good understanding of many deep sea families. We also have shown that new marine fish families will be very few, and new genera based on unique discovery of new species will be modest.

As discussed above, we assume that nearly all species in the Northern Hemisphere, including the Mediterranean Sea and Red Sea basins, have been found. Some additional species are expected from the northwestern Pacific, some deep-sea areas in the Middle Atlantic Ridge and the Bering Sea area. The number we expect to be discovered is perhaps only 200-300.

We anticipate some new shallow-reef species, but mainly in families with small-sized species, such as gobies and blennies, but most shallow-reef species have been found. We place that estimate at about 300 to 500. Deep reef species, however, are poorly known. Estimates as high as 1,500 yet-to-be-discovered species have been made (Pyle, 2005, abstract, $7^{\text {th }}$ Indo Pacific Fish Conference, based on 30\% above about 5,000 known shallow-reef species). Similarly, deep slope species are poorly known. More than 80 new marine species of sharks and rays have been described from Australian waters since 2005 (Last \& Stevens 2009), and more new species are being discovered in the Indo-Australian Archipelago. If the work in the Galapagos Archipelago is representative, then the increase of deep-slope species will be on the order of $10-15 \%$ new taxa-perhaps another 2,000 or more, however it is unknown how widespread deep slope species are.

Deep-sea species will continue to be found, especially in the Indian Ocean and the southern Pacific. Collecting in the deep sea is expensive, and this endeavor will continue for decades. We suggest that 800 deep-sea species remain to be described. It is anticipated that certain geographical areas will be most fruitful, such as southern Australia, South Pacific island areas and Indonesia.

Add to this the new taxa that may be revealed by molecular studies. A recent publication by Zemlak et al. (2009) shows interesting results for populations sharing a presence in South Africa and Australia. They suggest that sequence divergence patterns identify species-level differences between populations for a large 
number of species. They only studied populations at these two geographic extremes, and did not consider populations of these species in other areas. One of their pairs is known to involve misidentified specimens (W. Smith-Vaniz, pers. comm., 8 Mar. 2010 after communication with the persons making the identifications).

Mora et al. (2008) estimate that $21 \%$ of marine species remain to be discovered. This seems too low for the same reasons that limit our ability to make a good prediction using our approach. We are in agreement in the stage of completeness for some areas, such as shallow-reef-associated species and pelagic species. We suspect that their estimate for deep-sea species is a little too high; the deep-sea has been poorly sampled as they suggest, but many species are widespread. However, besides the deep sea, they do not mention the two habitats that we (W.N.E.) believe will provide the most new species in the next 20 or 30 years-deep-reef tropical areas and deep-slope habitats. In spatial terms, the shallow areas above these habitats have been sampled adequately, but deeper collections in the same area have not been sufficiently sampled. On a geographically-based special resolutions system as used by Mora et al., it would seem to be somewhat difficult to separate adjacent habitats.

A reasonable estimate would be at least 5,000 new species awaiting discovery in the next four decades, or an increase of about $30 \%$. We can assume a success rate of at least 90 to $95 \%$ of described versus valid species. In the last 20 years (1990-2009), 2,701 new species of marine fishes have been described based on Catalog of Fishes entries. Of these, over $97 \%$ are recognized as valid. The number of new marine species actually shows an increase (average 119 per year for 1990-1999 and 151 for 2000-2008). There is no reason to doubt that 2,500 new species will be described in the next 20 years, and 2,500 more in the 20 years thereafter.

\section{Acknowledgments}

The basic text was primarily prepared by Eschmeyer, with basin descriptions and analysis by Fricke. Fong and Polack assembled and proofed information for the tables and graphs; Fong prepared the tables and graphs and Polack checked for data accuracy and prepared some text sections. Fong also served as the programmer for the Catalog of Fishes project for the last 10 years.

We thank Jesse Ausubel and the Alfred P. Sloan Foundation for a grant to assist in preparation and publication. This is a contribution to the Census of Marine Life and its Ocean Biogeographical Information System (OBIS). Many persons have participated in the Catalog of Fishes database, and we thank them all. Rainer Froese (Fishbase) co-prepared a presentation by W.N.E. in 1999 of similar information for all fishes, and Froese was responsible for the design of some graphs that were modified for use in this work. Stan Blum, as the California Academy of Sciences' informatics specialist helped with technical details, as did librarians, administrators, the computer department, and other staff at the California Academy of Sciences.

The development of the Catalog of Fishes database was supported in many ways through the years by funding from granting agencies. Initial progress was mainly with the help of funds from the U.S. National Science Foundation. The California Academy of Sciences has supported the project for over 25 years.

Discussions and email exchanges with ichthyologists were helpful in the preparation of this paper. Many sent specific information, and we thank Gerry Allen, Diane Bray, Carole Baldwin, George Burgess, Tom Fraser, David Greenfield, Martin Gomon, Phil Heemstra, Hans Ho, Doug Hoese, Tomio Iwamoto, John McCosker, Bruce Mundy, John Randall and Richard Winterbottom. Many other assisted, included Edward Clark, Jill Johnson, Alan Leviton, Rob Robins and Alfred Thompson.

We are grateful for comments and suggestions on an early draft by Richard Winterbottom, Bill SmithVaniz and Derek Tittensor. Robert Lea generously reviewed all, and Lloyd Findley part of the manuscript, and they made many useful suggestions. Larry Page carefully edited the manuscript, and we thank him for his valuable assistance. 


\section{References}

Allen, G.R. \& Erdmann, M.V. (2009) Reef fishes of the Bird's Head Peninsula, West Papua, Indonesia. Check List, (3), 587-628.

Aristoteles (1545) Aristotelis stagiritae de historia animalivm lib. IX. De partibus animalivm, et earum avsis libri IIII. De Generatione animalivm libri V. Theodore Gaza Thessalonicesi interprete. Venetys [Venice] (H. Scotus), xvi (unnumbered) +307 (double) + xxii (unnumbered) pp.

Artedi, P. (1738) Synonymia nominum piscium fere omnium; in qua recensio fit nominum piscium,omnium facile authorum, qui undam de piscibus scripsere: uti Graecorum, Romanorum, Barbarorum, nec non omnium insequentium ichthyologorum, una cum nominibus inquilinis variarum nationum. Ichthyologiae pars 4 . Conradus Wishoff, Lugduni Batavorum [Leiden] (Conradus Wishoff), i 118 pp. + i-xxi.

Baldwin, C.C., Mounts, J.H., Smith, D.G. \& Weigt, L.A. (2009a) Genetic identification and color descriptions of early life-history stages of Belizean Phaeoptyx and Astrapogon (Teleostei: Apogonidae) with comments on identification of adult Phaeoptyx. Zootaxa, 2008, 1-22.

Baldwin, C.C., Weigt, L.A., Smith, D.G. \& Mounts, J.H. (2009b) Reconciling genetic lineages with species in western Atlantic Coryphopterus (Teleostei: Gobiidae). Smithsonian Contributions to the Marine Sciences, 38, 113-140.

Carpenter, K.E. \& Springer, V.G. (2005) The center of the center of marine shore fish biodiversity: the Philippine Islands. Environmental Biology of Fishes, 72, 467-480.

Chu, Y.-T., Meng, Q.-W., Hu, A.-S. \& Li, S. (1981) Description of four new species, a new genus and a new family of elasmobranchiate fishes from deep sea of the South China Sea. Oceanologica et Limnologica Sinica, 12, $103-116$.

Colborn, J., Crabtree, R.E., Shaklee, J.B., Pfeiler, E. \& Bowen, B.W. (2001) The evolutionary enigma of bonefishes (Albula spp.): cryptic species and ancient separations in a globally distributed shorefish. Evolution, 55, 807-820.

Cuvier, G.L.C.F.D. \& Valenciennes, A. (1828-1850) Histoire Naturelle des Poisons. 22 vols. Paris \& Strasbourg (Levrault).

Dasmahapatra, K.K., Elias, M., Hill, R I., Hoffman, J.I. \& Mallet, J. (2010) DNA BARCODING. Mitrrondrial DNA barcoding detects some species that are real, and some that are not. Molecular Ecology Resources, 10, $264-273$.

de Sylva, D.P. \& Eschmeyer, W.N. (1977) Systematics and biology of the deep-sea fish family Gibberichthyidae, a senior synonym of the family Kasidoroidae. Proceedings of the California Academy of Sciences. Fourth Series, 41, 215231.

Dor, M. (1984) CLOFRES Checklist of the Fishes of the Red Sea. Jerusalem (Israel Academy of Sciences and humanities), xxii + 437 pp., 2 maps.

Eschmeyer W.N. [ed.] (1998a) Catalog of Fishes. California Academy of Sciences. 3 vols. [Different authorship for different sections.]

Eschmeyer, W.N. (1998b) Appendix A. Genera and species and the International Code of Zoological Nomenclature. Pp. 2847-2881. In: Catalog of Fishes. California Academy of Sciences.

Eschmeyer, W.N. [ed.] (2010) Catalog of Fishes on-line. California Academy of Sciences. Available from: http:// research.calacademy.org/research/ichthyology/catalog/fishcatmain.asp. (Date of use 15 Jan. and 19 Feb. 2010).

Eschmeyer, W.N. \& Bailey, R.M. (1990) Genera of Fishes. California Academy of Sciences, v + 697 pp.

Eschmeyer, W.N. \& Hureau, J.-C. (1971) Sebastes mouchezi, a senior synonym of Helicolenus tristanensis, with comments of Sebastes capensis and zoogeographical considerations. Copeia 1971, 576-579.

Eschmeyer, W.N. \& Poss, S.G. (1976) Review of the scorpionfish genus Maxillicosta (Pisces: Scorpaenidae), with a description of three new species from the Australian-New Zealand region. Bulletin of Marine Science, 26 (4), 433449.

Forsskål, P.S. (1775) (Fish descriptions). In: Niebuhr, C. (ed.) Descriptiones animalium avium, amphibiorum, piscium, insectorum, vermium; quae in itinere orientali observavit Petrus Forskål. Prof. Haun. Post mortem auctoris editit Carsten Niebuhr. Adjuncta est material medica Kahirina atque tabula maris rubris geographica. Hauniae [Copenhagen] (Möller), $20+$ xxxiv + 164 pp., 1 map.

Fraser, T.H. \& Allen, G.R. (2010) Cardinalfish of the genus Apogonichthyoides Smith, 1949 (Apogonidae) with a description of a new species from the West-Pacific region. Zootaxa, 2348, 40-56.

Fricke, R. (1999) Fishes of the Mascarene Islands (Réunion, Mauritius, Rodriguez). An Annotated Checklist, with Descriptions of new species. Koeltz Scientific Books, Königstein, viii +759 pp.

Fricke, R. (2008) Authorship, availability and validity of fish names described by Peter (Pehr) Simon Fosskål and Johann Christian Fabricius in the 'Descriptiones animalium' by Carsten Niebuhr in 1775 (Pisces). Stuttgarter Beiträge zur Naturkunde (A), N.S., 1: 1-76, 2 pls.

Fricke, R., Bilecenoglu, M. \& Sari, H.M. (2007) Annotated checklist of fish and lamprey species (Gnathostomata and Petromyzontomorphi) of Turkey, including a Red List of threatened and declining species. Stuttgarter Beiträge zur Naturkunde (A), 706, 1-174.

Fricke, R. \& Eschmeyer, W.N. (2010) A guide to fish collections in the Catalog of Fishes database. http:// 
www.research.calacademy.org/research/ichthyology/catalog/fishcatmain.asp.

Fricke, R., Mulochau, T., Durville, P., Chabanet, P., Tessier, E. \& Letourneur, Y. (2009) Annotated checklist of the fish species (Pisces) of La Réunion, including a Red List of threatened and declining species. Stuttgarter Beiträge zur Naturkunde (A) N. S. 2, 1-168, figs. 1-4, tabs. 1-7.

Galil, B.S. (2008) Alien species in the Mediterranean Sea - which, when, where, why? Hydrobiologia, 606, $105-116$.

Golani, D. (1998) Distribution of Lessepsian migrant fish in the Mediterranean. Italian Journal of Zoology, 65 (suppl.), 95-99.

Golani, D. \& Bogorodsky, S.V. (2010) The Fishes of the Red Sea-Reappraisal and updated checklist. Zootaxa, 2463:1135.

Golani, D., Bray, D. \& Kuiter, R. (2008) Fishes of Australia's Southern Coast. Museum of Victoria, New Holland Publishers, $928 \mathrm{pp}$.

Goren, M. \& Dor, M. (1994) An Updated Checklist of the Fishes of the Red Sea. CLOFRES II. Jerusalem (The Israel Academy of Sciences and Humanities), xii + 120 pp.

Grove, J.S. \& Lavenberg, R.J. (1997) The Fishes of the Galapagos Islands. Stanford University Press. i+xliv + 1-863 pp.

Günther, A.C.L.G. (1859-1870) Catalogue of the Fishes in the British Museum. 8 vols. London (British Museum), xxxi +524 pp. (vol. 1), xxi +548 pp. (vol. 2), xxv + $586+$ x (vol. 3), xxi +534 pp. (vol. 4), xxii + 455 pp. (vol. 5), xv + 368 pp. (vol. 6), $\mathrm{xx}+512$ pp. (vol. 7), $\mathrm{xxv}+549$ pp. (vol. 8$)$.

Haedrich, R.L. (1969) A new family of aberrant stromateoid fishes from the equatorial Indo-Pacific. Dana Report, 76, 114.

Halas, D. \& Winterbottom, R. (2009) A phylogenetic test of multiple proposals for the origins of the East Indies coral reef biota. Journal of Biogeography, 36, 1847-1860.

Harold, A.S. \& Mooi, R.D. (1994) Areas of endemism: definition and recognition criteria. Systematic Biology, 43, 261266.

Heemstra, P.C. \& Hecht, T. (1986) Dinopercidae, a new family for the percoid marine fish genera Dinoperca Boulenger and Centrarchops Fowler (Pisces: Perciformes). Ichthyological Bulletin of the J. L. B. Smith Institute of Ichthyology, $51,1-20$.

Heemstra, P.C. \& Heemstra, E. (2004) Coastal Marine Fishes of Southern Africa. NISC and SIAIB, xxiv + 477 pp.

Heemstra, E., Heemstra, P.C., Smale, M.J., Hooper, T. \& Pelicier, D. (2004) Preliminary checklist of coastal fishes from the Mauritian island of Rodrigues. Journal of Natural History 38, 3315-3344.

Heemstra, P.C. \& Randall, J.E. (2009) A review of the anthiine fish genus Plectranthias (Perciformes: Serranidae) of the western Indian Ocean, with description of a new species, and a key to the species. Smithiana Bulletin, 10, 3-17.

Heemstra, P.C. \& Smith, M.M. (1980) Hexatrygonidae, a new family of stingrays (Myliobatiformes: Batoidea) from South Africa, with comments on the classification of batoid fishes. Ichthyological Bulletin of the J. L. B. Smith Institute of Ichthyology, 43, 1-17.

Hoese, D.F. \& Paxton, J.R. (2006) Fishes. Introduction to: Zoological Catalogue of Australia, BRS/CSIRO Publishing, Australia, 35, 1-27.

Hureau, J.-C. \& Monod, T. (1973) Check-list of the Fishes of the North-eastern Atlantic and of the Mediterranean. 2 vols. CLOFNAM. Paris (UNESCO), (vol. 1) i-xxii + 1-683, (vol. 2) 1-331.

Iglesias, S.P. (2009a) Actinopterygians from the North-eastern Atlantic and the Mediterranean (natural classification based on collection specimens). Volume 1, plates. Provisional version 05. Paris (MNHN), 141 pp., 67 pls. [Internet prepublication, 1 Nov. 2009.]

Iglesias, S.P. (2009b) Chondrichthyans from the North-eastern Atlantic and the Mediterranean (A natural classification based on collection specimens). Plates and text. Provisional version 03. Paris (MNHN), 69 pp., 32 pls. [Internet prepublication, 1 Nov. 2009.]

International Commission on Zoological Nomenclature (1999) International code of zoological nomenclature, 4th ed. International Trust for Zoological Nomenclature. xxix $+3-6 \mathrm{pp}$.

Iwamoto, T., Ho, H.-C. \& Shao, K.-T. (2009) Description of a new *Coelorinchus* (Macrouridae, Gadiformes, Teleostei) from Taiwan, with notable new records of grenadiers from the South China Sea. Zootaxa, 2326, 39-50.

Johnson, G.D., Paxton, J.R., Sutton, T.T., Satoh, T.P., Sado, T., Nishida, M. \& Miya, M. (2009) Deep-sea mystery solved: astonishing larval transformations and extreme sexual dimorphism unite three fish families. Biology Letters: Evolutionary Biology. [Published online, pp. 1-4.]

Khalaf, M. \& Zajonz, U. (2007) Fourteen additional fish species recorded from below $150 \mathrm{~m}$ depth in the Gulf of Aqaba, including Liopropoma lunulatum (Pisces: Serranidae), new record for the Red Sea. Fauna of Arabia, 23, 421-433.

Klunzinger, C.B. (1870) Synopsis der Fische des Rothen Meeres. I. Theil. Percoiden-Mugiloiden. Verhandlungen der K.K. zoologisch-botanischen Gesellschaft in Wien, 20, 669-834.

Klunzinger, C.B. (1871) Synopsis der Fische des Rothen Meeres. II. Theil. Verhandlungen der K.-K. zoologischbotanischen Gesellschaft in Wien, 21,441-688.

Klunzinger, C.B. (1884) Die Fische des Rothen Meeres. Eine kritische Revision mit Bestimmungstabellen. I. Teil. Stuttgart, ix $+133+[13] \mathrm{pp}, 13$ pls. 
Kotlyar, A.N. (1981) A new family, genus and species of Beryciformes, Hispidoberycidae fam. n. Hispidoberyx ambagiosus gen. et sp. n. (Beryciformes). Voprosy Ikhtiologii, 21, 411-416. [In Russian. English translation in Journal of Ichthyology, 21, 9-13.]

Lacepède, B.G.E. (1798-1803) Histoire Naturelle des Poisons. Paris. 5 vols.

Last, P.R. \& Stevens, J.D. (2009) Sharks and Rays of Australia. Fisheries Research \& Development Corporation, 513 pp.

Linnaeus, C. (1758) Systema naturae per regna tria naturae, secundum classes, ordines, genera, species, cum characteribus, differentiis, synonymis, locis. Tomus I. Editio decima, reformata. Holmiae (L. Salvius), ii + 824 pp.

Matallanas, J. (2009) Description of two new genera, Santelmoa and Bentartia and two new species of Zoarcidae (Teleostei: Perciformes) from the Southern Ocean. Polar Biology. [Prepublished online 6 Nov. 2009, without pagination. DOI 10.1007/s00300-009-0742-y].

Mavruk, S. \& Avsar, D. (2008) Non-native fishes in the Mediterranean from the Red Sea, by way of the Suez Canal. Review in Fish Biology and Fisheries, 18, 251-262.

McCosker, J.E. \& Rosenblatt, R.H. (in press) The fishes of the Galápagos Archipelago: an update. Proceedings of the California Academy of Sciences (Series 4), 61.

Mora, C., Tittensor, D.P. \& Myers, R.A. (2008) The completeness of taxonomic inventories for describing the global diversity and distribution of marine fishes. Proceedings of the Royal Society B, 275,149-155.

Pietsch, T.W. \& Anderson, W.D. [eds.] (1997) Collection Building in Ichthyology and Herpetology. American Society of Ichthyology and Herpetology. Special Publication 3, 593 pp.

Prokofiev, A.M. \& Kukuev, E.I. (2007) Systematics and distribution of the swallowerfishes of the genus Pseudoscopelus (Chisamodontidae). KMK Scientific Press Ltd. Moscow, 162 pp.

Rafinesque, C.S. (1810) Caratteri di alcuni nuovi generi e nuove specie di animali e piante della sicilia, con varie osservazioni sopra i medisimi. Messina, (part 1) [i-iv] 3-69 [70 blank] (part 2), ia-iva + 71-105 [106 blank], 20 pls.

Randall, J.E. (1994) Twenty-two new records of fishes from the Red Sea. Fauna of Saudia Arabia, 14, $259-275$.

Randall, J.E. (1998) Zoogeography of shore fishes of the Indo-Pacific region. Zoological Studies, 37, $227-268$.

Randall, J.E. (2007) Reef and Shore Fishes of the Hawaiian Islands. University of Hawai'i Sea Grant College Program, Honolulu, $546 \mathrm{pp}$.

Randall, J.E. \& Cea, A. (in press) Shore Fishes of Easter Island. University of Hawai'i Press, Honolulu. xii + 1-154.

Risso, A. (1810) Ichthyologie de Nice, ou Histoire Naturelle des Poissons du Département des Alpes Maritimes. Paris (F. Schoell), xxxvi + 388 pp., 11 pls.

Risso, A. (1827) Histoire Naturelle des Principales Productions de l'Europe Méridionale, et Particulièrement de Celles des Environs de Nice et des Alpes Maritimes. Vol. 3. Paris \& Strasbourg (F. G. Levrault), xvi + 480 pp., 16 pls.

Robertson, D.R. \& Smith-Vaniz, W.F. (2008) Rotenone: An essential but demonized tool for assessing marine fish diversity. BioScience, 58, 165-170.

Robertson, D.R. \& Smith-Vaniz, W.F. (2010) Use of clove oil in collecting coral reef fishes for research. Marine Ecology Progress Series, 401, 295-302.

Robins, C.R. \& de Sylva, D.P. (1965) The Kasidoroidae, a new family of mirapinniform fishes from the western Atlantic Ocean. Bulletin of Marine Science, 15, 189-201.

Rondelet, G. (1554) Libri de piscibus marinis, in quibus vera piscium effigies expressa sunt. Lugduni [Lyon] (M. Bonhomme), i-xiv (unnumbered) + 1-583 + i-xxiii (unnumbered). [Author's name spelled Gvilielmvs Rondeletius.]

Rüppell, W.P.E.S. (1828-1830) Atlas zu der Reise im Nördlichen Africa. Frankfurt am Main, $141+3$ pp., 35 col. pls. [Part 1 (1828):1-26, Pls. 1-6; part 2 (1829):27-94, Pls. 7-24; part 3 (1830):95-141, Pls. 25-35.]

Rüppell, W.P.E.S. (1835-1838) Neue Wirbelthiere zu der Fauna von Abyssinien Gehörig. Frankfurt am Main, 148 pp., 33 pls. [1835:1-28, Pls. 1-7; 1836:29-52, Pls. 8-14; 1837:53-80, Pls. 15-21; 1838:81-148, Pls. 22-33.]

Salviani, I. (1588) Aquatilium Animalium Historiae Liber Primus. Roma (I. Salviani), viii (unnumbered) + 256 (double) pp.

Sato, T. \& Nakabo, T. (2002) Paraulopidae and Paraulopus, a new family and genus of aulopiform fishes with revised relationships within the order. Ichthyological Research, 49, 25-46.

Schwarzhans, W., Møller, P.R. \& Nielsen, J.G. (2005) Review of the Dinematichthyini (Teleostei: Bythitidae) of the Indo-West Pacific. Part I. Diancistrus and two new genera with 26 new species. The Beagle, Records of the Museums and Art Galleries of the Northern Territory, 21, 73-163.

Smith-Vaniz, W.F., Jelks, H.L. \& Rocha, L.A. (2006) Relevance of cryptic fishes in biodiversity assessments: a case study at Buck Island Reef National Monument, St. Croix. Bulletin of Marine Science, 79, 17-48.

Song, J.-K. \& Parenti, L.R. (1995) Clearing and staining whole fish specimens for simultaneous demonstration of bone, cartilage, and nerves. Copeia 1995, 114-118.

Springer, V.G. (1982) Pacific plate biogeography, with special reference to shorefishes. Smithsonian Contributions to Zoology, 367, 1-184.

Taylor, L.R., Jr., Compagno, L.J.V. \& Struhsaker, P.J. (1983) Megamouth--a new species, genus, and family of lamnoid shark (Megachasma pelagios, family Megachasmidae) from the Hawaiian Islands. Proceedings of the California Academy of Sciences (Series 4), 43, 87-110. 
Taylor, W.R. (1967) An enzyme method of clearing and staining small vertebrates. Proceedings of the United States National Museum, 122, 1-17.

Thacker, C.E. (2009) Phylogeny of Gobioidei and placement within Acanthomorpha, with a new classification and investigation of diversification and character evolution. Copeia 2009, 93-104.

Waller, R.A. \& Eschmeyer, W.N. (1965) A method for preserving color in biological specimens. BioScience, $15,361$.

Whitehead, P.J.P., Bauchot, M.-L., Hureau, J.-C., Nielsen, J. \& Tortonese, E. (1984-1986) Fishes of the North-eastern Atlantic and the Mediterranean. Paris, (UNESCO); 1 (1984), 510 pp.; 2 (1986), 511-1007; 3 (1986), $1008-1473$.

Winterbottom, R. (1985) Revision of the congrogadid Haliophis (Pisces:Perciformes), with the description of a new species from Indonesia, and comments on the endemic fish fauna of the northern Red Sea. Canadian Journal of Zoology, 63, 209-217.

Zemlak, T.S., Ward, R.D., Connell, A.D., Holmes, B.H. \& Hebert, P.D.N. (2009) DNA barcoding reveals overlooked marine fishes. Molecular Ecology Resources, 9 (suppl. 1), 237-242. 